\title{
Impacts of the Denver Cyclone on regional air quality and aerosol formation in the Colorado Front Range during FRAPPÉ 2014
}

\author{
Kennedy T. Vu ${ }^{1}$, Justin H. Dingle ${ }^{1}$, Roya Bahreini ${ }^{1,2}$, Patrick J. Reddy ${ }^{3, a}$, Eric C. Apel ${ }^{3}$, Teresa L. Campos $^{3}$, \\ Joshua P. DiGangi ${ }^{4}$, Glenn S. Diskin ${ }^{4}$, Alan Fried ${ }^{5}$, Scott C. Herndon ${ }^{6}$, Alan J. Hills ${ }^{3}$, Rebecca S. Hornbrook ${ }^{3}$, \\ Greg Huey $^{7}$, Lisa Kaser ${ }^{3}$, Denise D. Montzka ${ }^{3}$, John B. Nowak ${ }^{6}$, Sally E. Pusede ${ }^{8}$, Dirk Richter ${ }^{5}$, Joseph R. Roscioli ${ }^{6}$, \\ Glen W. Sachse ${ }^{9}$, Stephen Shertz ${ }^{3}$, Meghan Stell ${ }^{3}$, David Tanner ${ }^{7}$, Geoffrey S. Tyndall ${ }^{3}$, James Walega ${ }^{5}$, \\ Peter Weibring ${ }^{5}$, Andrew J. Weinheimer ${ }^{3}$, Gabriele Pfister ${ }^{3}$, and Frank Flocke ${ }^{3}$ \\ ${ }^{1}$ Environmental Toxicology Graduate Program, University of California, Riverside, CA 92521, USA \\ ${ }^{2}$ Department of Environmental Sciences, University of California, Riverside, CA 92521, USA \\ ${ }^{3}$ Atmospheric Chemistry Observations \& Modeling Laboratory, National Center for Atmospheric Research, Boulder, CO \\ 80301, USA \\ ${ }^{4}$ Chemistry and Dynamics Branch, NASA Langley Research Center, Hampton, VA 23681, USA \\ ${ }^{5}$ Institute for Arctic and Alpine Research, University of Colorado, Boulder, CO 80303, USA \\ ${ }^{6}$ Aerodyne Research, Inc., Billerica, MA 01821, USA \\ ${ }^{7}$ Department of Earth and Atmospheric Sciences, Georgia Institute of Technology, Atlanta, GA 30033, USA \\ ${ }^{8}$ Department of Environmental Sciences, University of Virginia, Charlottesville, VA 22904, USA \\ ${ }^{9}$ National Institute of Aerospace, Hampton, VA 23666, USA \\ ${ }^{\mathrm{a}}$ visitor at: NCAR, Boulder, CO 80301, USA
}

Correspondence to: Roya Bahreini (roya.bahreini@ucr.edu)

Received: 17 June 2016 - Published in Atmos. Chem. Phys. Discuss.: 30 June 2016

Revised: 1 September 2016 - Accepted: 10 September 2016 - Published: 27 September 2016

\begin{abstract}
We present airborne measurements made during the 2014 Front Range Air Pollution and Photochemistry Experiment (FRAPPÉ) project to investigate the impacts of the Denver Cyclone on regional air quality in the greater Denver area. Data on trace gases, non-refractory submicron aerosol chemical constituents, and aerosol optical extinction $\left(\beta_{\text {ext }}\right)$ at $\lambda=632 \mathrm{~nm}$ were evaluated in the presence and absence of the surface mesoscale circulation in three distinct study regions of the Front Range: In-Flow, Northern Front Range, and the Denver metropolitan area. Pronounced increases in mass concentrations of organics, nitrate, and sulfate in the Northern Front Range and the Denver metropolitan area were observed during the cyclone episodes (27-28 July) compared to the non-cyclonic days (26 July, 2-3 August). Organic aerosols dominated the mass concentrations on all evaluated days, with a $45 \%$ increase in organics on cyclone days across all three regions, while the increase during the cyclone episode was up to $\sim 80 \%$ over the Denver metropolitan area. In the most aged air masses $\left(\mathrm{NO}_{x} / \mathrm{NO}_{y}<0.5\right)$, back-
\end{abstract}

ground organic aerosols over the Denver metropolitan area increased by a factor of $\sim 2.5$ due to transport from Northern Front Range. Furthermore, enhanced partitioning of nitric acid to the aerosol phase was observed during the cyclone episodes, mainly due to increased abundance of gas phase ammonia. During the non-cyclone events, $\beta_{\text {ext }}$ displayed strong correlations $(r=0.71)$ with organic and nitrate in the Northern Front Range and only with organics $(r=0.70)$ in the Denver metropolitan area, while correlation of $\beta_{\text {ext }}$ during the cyclone was strongest $(r=0.86)$ with nitrate over Denver. Mass extinction efficiency (MEE) values in the Denver metropolitan area were similar on cyclone and non-cyclone days despite the dominant influence of different aerosol species on $\beta_{\text {ext }}$. Our analysis showed that the meteorological patterns associated with the Denver Cyclone increased aerosol mass loadings in the Denver metropolitan area mainly by transporting aerosols and/or aerosol precursors from the northern regions, leading to impaired visibility and air quality deterioration. 


\section{Introduction}

Atmospheric aerosols are of interest due to their impacts on human health, visibility, and climate radiative forcing through scattering and absorption of solar radiation (Monks et al., 2009; Stocker et al., 2013). Notably, numerous studies have shown that aerosols contribute to respiratory and cardiac disease, leading to an increase in morbidity and mortality in humans (Dockery et al., 1993; Dockery and Schwartz, 1995; Pope et al., 1995, 2002, 2009; Pope III et al., 1995; Bascom et al., 1996; Pöschl, 2005; Valavanidis et al., 2008). Moreover, ecological changes in lakes and national forests from nitrogen deposition are a driving concern for the sustainability of the ecosystem (Wilson and Spengler, 1996; Baron et al., 2000; Williams and Tonnessen, 2000; Blett et al., 2004; Burns, 2004; Seinfeld and Pandis, 2012).

Urban air is comprised of a highly complex mixture of gaseous and particulate pollutants, including volatile organic compounds (VOCs), nitrogen oxides ( $\mathrm{NO}$ and $\mathrm{NO}_{2}$ ), sulfur dioxide $\left(\mathrm{SO}_{2}\right)$, ozone $\left(\mathrm{O}_{3}\right)$, and fine particulate matter $\left(\mathrm{PM}_{2.5}\right)$ and is detrimental to the environment and to the well-being of the public. A significant amount of submicron aerosol mass in the troposphere is comprised of organic aerosols (OAs), but direct sources, composition, and formation processes of OA are still not fully understood (Pandis et al., 1992; Turpin and Huntzicker, 1995; Odum et al., 1996; Schell et al., 2001; Claeys et al., 2004; Kroll et al., 2006; Volkamer et al., 2006; Kroll and Seinfeld, 2008; Hallquist et al., 2009; Jimenez et al., 2009; Zhang et al., 2011). Generally, OAs are comprised of primary particles emitted into the atmosphere (i.e., primary organic aerosols; POAs) and products formed from multiphase chemical reactions as secondary organic aerosols (SOAs). Several important factors including aerosol composition and size determine the extent to which aerosols affect the environment and health.

The Colorado Front Range continues to face challenges attributed to air quality. In 2007, the Northern Front Range (NFR) and the Denver metropolitan area (DM) were designated as federal non-attainment areas for the federal $8 \mathrm{~h}$ ozone standard ( $75 \mathrm{ppbv})$, averaged over 3 years (EPA, 2008). Since May 2016, this area has been classified as a "moderate" non-attainment regions for failure to attain the federal $8 \mathrm{~h}$ ozone standard of $75 \mathrm{ppbv}$ (averaged over 3 years) (EPA, 2016). Furthermore, under the Clean Air Act, the US EPA Regional Haze Rule mandates the reduction in anthropogenic emissions to achieve visibility improvement in wilderness areas, including Colorado's Rocky Mountain National Park. Additionally, the State of Colorado has implemented a visibility standard based on optical extinction of $76 \mathrm{M} \mathrm{m}^{-1}$, averaged within a $4 \mathrm{~h}$ period when relative humidity (RH) is less than $70 \%$. This measure of total optical extinction is provided by an Optec LRT-2 long-range transmissometer at $550 \mathrm{~nm}$ between east Denver and downtown $\left(39^{\circ} 44^{\prime} 8.52^{\prime \prime} \mathrm{N}, 104^{\circ} 57^{\prime} 29.50^{\prime \prime} \mathrm{W}\right)$ from $08: 00$ to $16: 00$ (MST in winter and MDT in summer). The establishment of the Denver visibility standard-setting is covered in detail by Ely et al. (1993).

The complex topography of the Colorado Front Range leads to terrain-induced flows and mesoscale circulations that have a significant impact on air quality. These include cycles of daytime thermally driven upslope from the plains into the mountains and decoupled, downslope nighttime drainage and slope flows which can transport and pool particulates and precursors of secondary aerosols into the wider Platte River valley between Denver and Greeley, Colorado. Thermally driven upslope flows or cool moist northeasterly upslope flows can lead to secondary aerosol formation and poor visibility (Neff, 1997). Many of these upslope flows can be caused by low-pressure formation in southern Colorado, a lee trough or line of lower pressure along the foothills, and the Denver Cyclone. The Denver Cyclone (Wilczak and Glendening, 1988; Wilczak and Christian, 1990; Szoke, 1991; Szoke et al., 2006) is a mesoscale cyclonic gyre which can form when there are southeasterly flows across the Palmer Divide (an east-to-west feature of higher terrain to the south of Denver) and a layer of high stability above the surface mixed layer and below $700 \mathrm{hPa}$ (Szoke and Augustine, 1990; Reddy and Pfister, 2016). Reddy et al. (1995) have shown that the Denver Cyclone plays a key role in the degradation of visibility and exceedances of the state visibility standard of $76 \mathrm{M} \mathrm{m}^{-1}$ during the winter, but our study is the first to examine the summertime impacts of the Denver Cyclone during an intensive air quality study with a detailed suite of aircraft and surface measurements.

Air pollution in the Northern Front Range is impacted by vehicular emissions from growing urbanization in the Denver metropolitan area, local powerplants, agriculture (e.g., concentrated animal feeding operations - CAFOs), and extensive oil and gas $(\mathrm{O} \& \mathrm{G})$ explorations. Recent studies have shown $\mathrm{O} \& \mathrm{G}$ emissions of non-methane hydrocarbons (NMHC) such as short-chain alkanes $\left(\mathrm{C}_{1}-\mathrm{C}_{4}\right)$ and alkenes act as precursors to ozone (Pétron et al., 2012, 2014; Edwards et al., 2013; Gilman et al., 2013; Karion et al., 2013), but the potential for these emissions to contribute to primary and secondary OA in the region has not been investigated. Additionally, agricultural practices and powerplant operations in the greater Colorado region contribute to visibility impairment and ecosystem degradation through formation of secondary nitrate and sulfate-containing compounds (Williams and Tonnessen, 2000; Nanus et al., 2003; Blett et al., 2004; Burns, 2004; Boy et al., 2008; Malm et al., 2013; Mast and Ely, 2013; T. M. Thompson et al., 2015).

Emission sources and meteorological conditions affecting air quality in the greater Front Range have been previously studied in the region. The 1973 Denver Air Pollution Study (Russell, 1976), focused on episodes of winter pollution in Denver, described occurrences of rapid dispersal of pollutants to the north-northeast of Denver due to strong winds and recurring reversal of winds, bringing aged pollutants back to the urban center. Additionally, the Denver Haze Study 
conducted in the winter of 1978-1979 and the 1987-1988 Metro Denver Brown Cloud study provided objective apportionment to the observed brown cloud pollution over Denver. The occurrence of the wintertime inversion layer and emissions from the local gas and coal-burning powerplants had a profound effect on air quality and visibility degradation. Among the measured aerosol species, elemental carbon, ammonium sulfate, and ammonium nitrate contributed to the majority of optical extinction, decreasing visibility in the visible range by about 38,20 , and $17 \%$, respectively (Countess et al., 1980; Groblicki et al., 1981; Wolff et al., 1981; Watson et al., 1988; Neff, 1989).

During 1996-1997, measurements of aerosol composition and inorganic aerosol precursors were carried out in winter and summer months at several urban and rural sites during the Northern Front Range Air Quality Study (NFRAQS). Summertime $24 \mathrm{~h} \mathrm{PM}_{2.5}$ mass concentrations at different sites ranged from 4 to $26 \mu \mathrm{g} \mathrm{m}^{-3}$, while winter measurements indicated variable $\mathrm{PM}_{2.5}$ mass in the range of $1-51 \mu \mathrm{g} \mathrm{m}^{-3}$, depending on the sampling location and year (Watson et al., 1998). During summer 1996 and at an urban site northeast of downtown Denver, OA was the most dominant component of $\mathrm{PM}_{2.5}$ mass, contributing $46 \%$ of the mass with an average organic carbon mass of $4.2 \mu \mathrm{g} \mathrm{m}^{-3}$ (Watson et al., 1998). During this time, secondary inorganic aerosol contributed to $18 \%$ of $\mathrm{PM}_{2.5}$ mass, about $50 \%$ lower than the wintertime observations, with average sulfate and nitrate concentrations of $\sim 1.4-1.5$ and $0.9-1.2 \mu \mathrm{g} \mathrm{m}^{-3}$, respectively (Watson et al., 1998). On average, crustal components of $\mathrm{PM}_{2.5}$ were low in concentration (less than $0.5 \mu \mathrm{g} \mathrm{m}^{-3}$ ) during summer 1997 (Watson et al., 1998). Since the late 1990s, emissions in the Front Range have likely changed due to changes in the vehicular fleet, urbanization, and growth in O \& G-related activities. Despite these changes, recent comprehensive characterization of summertime air quality in the Colorado Front Range has been lacking. More importantly, limited studies have evaluated the summertime air quality implications of the Denver Cyclone that result in transport of pollutants from the Northern Front Range to the urban center.

During the summer of 2014, two major field campaigns, the Front Range Air Pollution and Photochemistry Experiment (FRAPPÉ) cosponsored by NSF/NCAR and the Colorado Department of Public Health and Environment (CDPHE), and the fourth deployment of the NASA DISCOVERAQ were carried out to study summertime atmospheric pollution in the Northern Colorado Front Range. In this paper, we focus our analysis on the data obtained during FRAPPÉ to assess the impact of the Denver Cyclone on the region's air quality (Flocke, 2015).

\section{Measurements}

\subsection{Field campaign}

Airborne measurements were made during the Front Range Air Pollution and Photochemistry Experiment (FRAPPÉ) from 16 July through 18 August 2014. Fifteen research flights were conducted over the northern Colorado plains, foothills, and west of the Continental Divide to sample air masses under the influence of diverse sources and meteorological patterns that impact the overall air quality in the region. The C-130 flight tracks, overlaid on a map including the location of active oil and gas wells in the region, are shown in the Supplement of this paper (Fig. S1) (COGCC, 2016). In this analysis, measurements made in the geographical area of the greater Denver metropolitan area (latitudes of $39^{\circ} 27^{\prime} 00^{\prime \prime}-40^{\circ} 15^{\prime} 36^{\prime \prime} \mathrm{N}$ and longitudes of $104^{\circ} 17^{\prime} 24^{\prime \prime}-105^{\circ} 19^{\prime} 48^{\prime \prime} \mathrm{W}$ ) and northern Colorado counties in NFR (latitudes of $40^{\circ} 15^{\prime} 58^{\prime \prime}-41^{\circ} 00^{\prime} 00^{\prime \prime} \mathrm{N}$ and longitudes of $104^{\circ} 45^{\prime} 00^{\prime \prime}-105^{\circ} 19^{\prime} 48^{\prime \prime} \mathrm{W}$ ) during days when the Denver Cyclone was strongly developed (27-28 July) are contrasted with measurements made during days without the presence of a Denver Cyclone (26 July, 2-3 August). Airborne data presented in this analysis are limited to measurements in the boundary layer (i.e., altitudes below $2300 \mathrm{~m}$ east of the foothills as further discussed in Sect. 2.3) to capture air masses impacted by various local sources.

\subsection{Instrumentation}

In situ size-resolved composition measurements of nonrefractory submicron aerosols $\left(\mathrm{NR}-\mathrm{PM}_{1}\right)$; organic $\mathrm{OA}$; nitrate $-\mathrm{NO}_{3}^{-}$; sulfate $-\mathrm{SO}_{4}^{2-}$; ammonium $-\mathrm{NH}_{4}^{+}$; and chloride $-\mathrm{Cl}^{-}$) were made with an aerosol mass spectrometer equipped with a compact time-of-flight detector (mAMS, Aerodyne Inc.). Principle details of the instrument are described in depth elsewhere (Jayne et al., 2000; Drewnick et al., 2005; Canagaratna et al., 2007). In short, aerosols form a narrow particle beam by passing through an aerodynamic lens system (Liu et al., 1995a, b). After traveling through the high-vacuum particle time-of-flight chamber and impacting an inverted-cone tungsten vaporizer at approximately $600^{\circ} \mathrm{C}$, non-refractory components of aerosols are evaporated and ionized by electron impact ionization. The data are acquired at $15 \mathrm{~s}$ intervals in two distinct acquisition modes (Jimenez et al., 2003). In the particle time-of-flight (PToF) mode, the particle beam is modulated by a multi-slit chopper system, allowing for particle sizing. In the mass spectrometry mode (MS), the chopper completely blocks or opens the particle beam, allowing the determination of the ensemble mass spectra of aerosol species.

The mass response of the mAMS was calibrated regularly by sampling size-selected, dry, monodisperse $\mathrm{NH}_{4} \mathrm{NO}_{3}$ particles with the procedure and calculations described in previous literature to determine the ionization efficiency (IE) of 
nitrate and ammonium (Jimenez et al., 2003; Zhang et al., 2005). The average ratio of the nitrate ionization efficiency ratio to the air beam signal was $(2.57 \pm 0.26) \times 10^{-13}$ from five calibrations performed during the study, indicating stability of the instrument throughout the project. Compositiondependent collection efficiency was applied to all the data in this study (Middlebrook et al., 2012). mAMS data analysis was carried out using the standard SQUIRREL analysis software (v1.56, Sueper, 2014) with Igor Pro 6.37 (WaveMetrics, Lake Oswego, OR).

Ambient aerosols were sampled through a secondary diffuser inside a forward-facing NCAR High-performance Instrumented Airborne Platform for Environmental Research (HIAPER) modular inlet (HIMIL) (Rogers, 2011), mounted under the aircraft, with a total residence time of $0.5 \mathrm{~s}$ between the HIMIL inlet and the mAMS. Assuming the sample flow reached the same temperature as the cabin air within this time, relative humidity of the sample flow was estimated to be less than $40 \%$ for the data presented here. For the ambient conditions in the boundary layer (i.e., $20^{\circ} \mathrm{C}$ and $70 \mathrm{kPa}$ ), the secondary diffuser inlet was estimated to be a $\mathrm{PM}_{2}$ inlet, i.e., with $50 \%$ transmission efficiency of $2 \mu \mathrm{m}$ spherical particles (density of $1500 \mathrm{~kg} \mathrm{~m}^{-3}$ ). A pressurecontrolled inlet (PCI) (Bahreini et al., 2008) was used to maintain a constant pressure of 350 Torr in the mAMS inlet to eliminate fluctuations in particle size and transmission efficiency with ambient pressure variations.

Measurements of gas phase tracers used in this analysis include carbon monoxide (CO), measured by vacuum UV resonance fluorescence (Gerbig et al., 1999; Holloway et al., 2000; Takegawa et al., 2001) on the C130 and by Differential Absorption Carbon Monoxide Measurement (DACOM) instrument with an in situ diode laser spectrometer system (Choi et al., 2008; Warner et al., 2010) on the NASA DISCOVER-AQ P-3 aircraft. $\mathrm{NO}_{x}$ (NO and $\mathrm{NO}_{2}$ ), were measured by chemiluminescence (Ridley et al., 2004). Mixing ratios of $\mathrm{NO}_{y}$ (total reactive oxidized nitrogen species) were estimated as the sum of $\mathrm{NO}_{x}$, aerosol nitrate $\left(\mathrm{NO}_{3}^{-}\right)$, nitric acid $\left(\mathrm{HNO}_{3}\right)$ (Huey et al., 1998; Huey, 2007), peroxyacetyl nitrate (PAN), and peroxypropionyl nitrate (PPN), measured by chemical ionization mass spectrometry (CIMS) (Slusher et al., 2004), and alkyl nitrates (ANs), measured using thermal dissociation-laser induced fluorescence (TD-LIF) (Thornton et al., 2000; Day et al., 2002). A compact quantum cascade tunable infrared laser differential absorption spectrometer (QC-TILDAS) was used for ammonia $\left(\mathrm{NH}_{3}\right)$ measurements (Ellis et al., 2010), while $\mathrm{C}_{2} \mathrm{H}_{6}$ and $\mathrm{CH}_{2} \mathrm{O}$ were measured by mid-infrared spectrometry using the Compact Atmospheric Multi-species Spectrometer (CAMS) (Weibring et al., 2006, 2007; Richter et al., 2015). Volatile organic compounds (VOCs), including $\mathrm{C}_{6}-\mathrm{C}_{9}$ aromatics, $i$-pentane, and $n$-pentane were measured by online proton-transfer mass spectrometry (PTRMS) and the Trace Organic Gas Analyzer (TOGA), respec- tively (Lindinger et al., 1998; de Gouw and Warneke, 2007; Apel et al., 2015).

\subsection{Data processing}

Reported data are a subset of the FRAPPÉ 2014 data collected aboard the NSF/NCAR C-130 aircraft. All data presented here were limited to air masses sampled below $\sim 2300 \mathrm{~m}$ a.s.l. and values for aerosol concentrations are reported at standard temperature and pressure (STP; $1013 \mathrm{hPa}$ and $273 \mathrm{~K}, \mu \mathrm{g} \mathrm{s} \mathrm{m}^{-3}$ ). Additionally, data were chosen from days before (26 July), during (27-28 July), and after (23 August) the Denver Cyclone period, with the strongest features of the cyclone being observed on 27 July. To evaluate the impact of the Denver Cyclone in different regions of the Front Range, measurements were analyzed in three regions, labeled as In-Flow, NFR, and DM, based on cluster analysis of wind patterns and aerosol and gas phase tracer concentrations observed on the day with the strongest Denver Cyclone, 27 July. Flight tracks and outlines of the latitude and longitudinal boxes for these regions are shown in Fig. 1.

To assess the extent of boundary layer mixing and dilution, potential temperature profiles measured by the Pennsylvania State University NATIVE integrated ozonesonde (A. M. Thompson et al., 2015), launched near Platteville $\left(40^{\circ} 10^{\prime} 53^{\prime \prime} \mathrm{N}, 104^{\circ} 43^{\prime} 36^{\prime \prime} \mathrm{W}\right)$ during NASA DISCOVERAQ, were examined. Except for 26 July when at 12:00 MST the boundary layer (BL) height was observed to be at $2200 \mathrm{~m}$ a.s.l., midday BL heights on other days were consistently at $\sim 3400-3600 \mathrm{~m}$ a.s.l. Additionally, except for the high, constant-altitude legs, the sampling altitude on 26 July and the other flights was lower than $\sim 2000$ and $\sim 2300$ m a.s.l., respectively. Therefore, the data discussed here represent mainly the altitudes of the boundary layer air masses. Variability in the extent of boundary layer dilution due to differences in daytime flight hours (takeoff times of 08:30-14:00 MST) showed some effects on the observations; however, as further discussed in Sect. 3.3.1, dilution differences were not the main driving factor in the observed trends of absolute concentrations of gaseous and aerosol species.

\subsection{ISORROPIA II modeling}

An aerosol thermodynamics model, ISORROPIA II (Nenes, 2013) was used to predict the phase and composition of the major inorganic aerosol components. Detailed equilibrium relations and thermodynamic parameters used in ISORROPIA II are outlined in Fountoukis and Nenes (2007). The model was initiated with the average measured values of temperature $(T)$, relative humidity $(\mathrm{RH})$, and total concentrations of ammonium $\left(\mathrm{NH}_{3(g)}+\mathrm{NH}_{4}^{+}\right)$, sulfate $\left(\mathrm{SO}_{4}^{2-}\right)$, and nitrate $\left(\mathrm{HNO}_{3(g)}+\mathrm{NO}_{3}^{-}\right)$. Assuming chemical equilibrium and the presence of metastable aerosols, the model predicted concentrations of sulfate, nitrate, and ammonium present in the gas and aerosol phase, allowing the estimation of the aerosol 
(a)
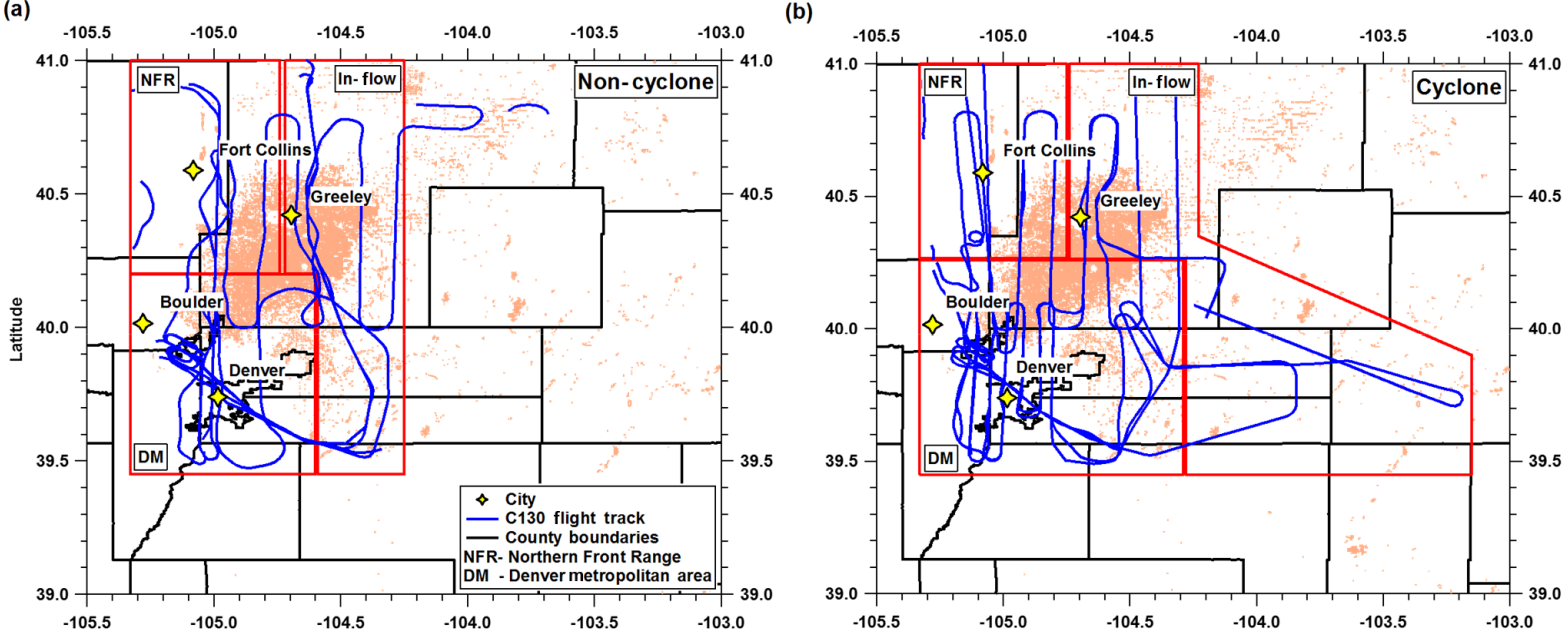

Longitude

Figure 1. C-130 flight tracks in the Colorado Front Range for (a) non-cyclone days (26 July, 2-3 August 2014) and (b) cyclone days (2728 July 2014); red marked boundaries represent three different study regions: In-Flow, Northern Front Range (NFR), and Denver metropolitan area (DM). Peach colored markers represent active oil and natural gas wells in the region with data available from the Colorado Oil and Gas Conservative Commission.

nitrate fraction $\left(f_{\mathrm{NO}_{3}}=\mathrm{NO}_{3}^{-} /\left(\mathrm{HNO}_{3(g)}+\mathrm{NO}_{3}^{-}\right)\right)$at equilibrium.

\section{Results and discussion}

\subsection{Meteorology}

Meteorological measurements presented in Table 1 show average ambient temperature $(T), \mathrm{RH}$, and wind speed (WS) during selected flights for each of the three regions of interest on non-cyclone and cyclone days. During non-cyclone days, $T, \mathrm{RH}$, and WS were similar in all regions with an average of $23 \pm 1.6^{\circ} \mathrm{C}, 35 \pm 6.0 \%$, and $3.4 \pm 1.5 \mathrm{~m} \mathrm{~s}^{-1}$, respectively. During the cyclonic episode, the average $T$ across all three regions was $22 \pm 1.6^{\circ} \mathrm{C}$ and lower by $2-8 \%$ in NFR and DM areas compared to the In-Flow region. Additionally, average RH was higher in NFR and DM (64-70\%) compared to the In-Flow region $(37 \%)$ during this mesoscale event. We further address the importance of the contrast in RH between the events for aerosol nitrate partitioning in Section 3.5. Average wind speed showed a $65 \%$ increase in the In-Flow region $\left(6.3 \pm 1.9 \mathrm{~m} \mathrm{~s}^{-1}\right)$ during the cyclone event, with a gradual decrease in the average wind speeds across NFR and DM.

We used analysis runs of the National Centers for Environmental Prediction (NCEP) $13 \mathrm{~km}$ resolution Rapid Refresh (RAP) model for the periods of interest. These analysis runs reflect extensive assimilation of observational data. Plots were generated and analyzed with surface wind vectors, $\mathrm{RH}$, and specific humidity for days with and without the influence of the cyclone. Surface wind direction and speed for both case scenarios are shown in Figs. 2-3 and S2-S3.
Table 1. Average temperature $\left(T,{ }^{\circ} \mathrm{C}\right)$, relative humidity $(\mathrm{RH}, \%)$, and wind speed (WS, $\mathrm{m} \mathrm{s}^{-1}$ ) for measurements separated into InFlow, NFR, and DM regions during the non-cyclone and cyclone episodes.

\begin{tabular}{lccc}
\hline Region & $T\left({ }^{\circ} \mathrm{C}\right)$ & $\mathrm{RH}(\%)$ & $\mathrm{WS}\left(\mathrm{m} \mathrm{s}^{-1}\right)$ \\
\hline \multicolumn{4}{c}{ Non-cyclone (26 July, 2-3 August) } \\
\hline In-Flow & $22.8 \pm 1.7$ & $33.3 \pm 4.6$ & $3.8 \pm 1.4$ \\
NFR & $22.5 \pm 1.7$ & $38.4 \pm 6.9$ & $3.5 \pm 1.6$ \\
DM & $23.7 \pm 1.4$ & $34.0 \pm 6.6$ & $3.0 \pm 1.3$ \\
\hline \multicolumn{4}{c}{ Cyclone (27-28 July) } \\
\hline In-Flow & $22.4 \pm 1.4$ & $37.0 \pm 5.5$ & $6.3 \pm 1.9$ \\
NFR & $21.8 \pm 1.3$ & $70.4 \pm 7.2$ & $4.1 \pm 1.4$ \\
DM & $20.6 \pm 2.0$ & $64.5 \pm 7.7$ & $3.2 \pm 1.4$ \\
\hline
\end{tabular}

As previously described by Toth and Johnson (1985), cyclic terrain-driven circulations in this region are common during the summer when synoptic-scale influences are weak. When synoptic-scale flows are weak and the Denver Cyclone is not active, nighttime and early morning slope and drainage flows are formed as radiative cooling in the higher terrain to the north, west, and south of DM causes denser, cooler air to flow downhill, with a general westerly component along the valleys over Denver (Figs. 2a, c and S2a, c). The surrounding terrain channels this drainage flow to the northeast through Denver. This flow can carry emissions away from the urban center. During the day, typical thermally driven flows reverse these winds, and transport is generally towards the higher terrain. This daytime regime can also interact with 


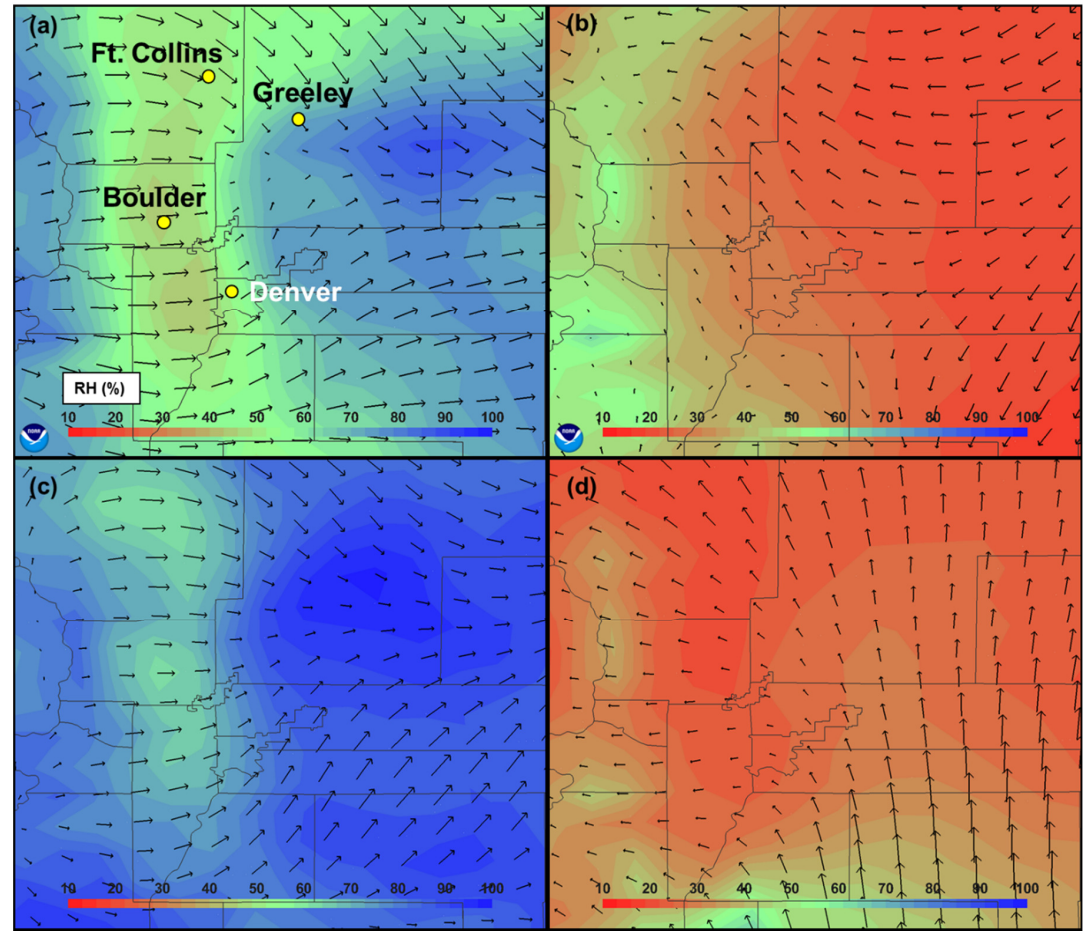

Figure 2. RAP model analysis runs at $13 \mathrm{~km}$ resolution for (a, b) 26 July 2014 (12:00 UTC (05:00 MST), 21:00 UTC (14:00 MST), respectively) and (c, d) 2 August 2014 (12:00, 21:00 UTC, respectively). Arrows show surface wind vectors, while the color scale represents surface RH.

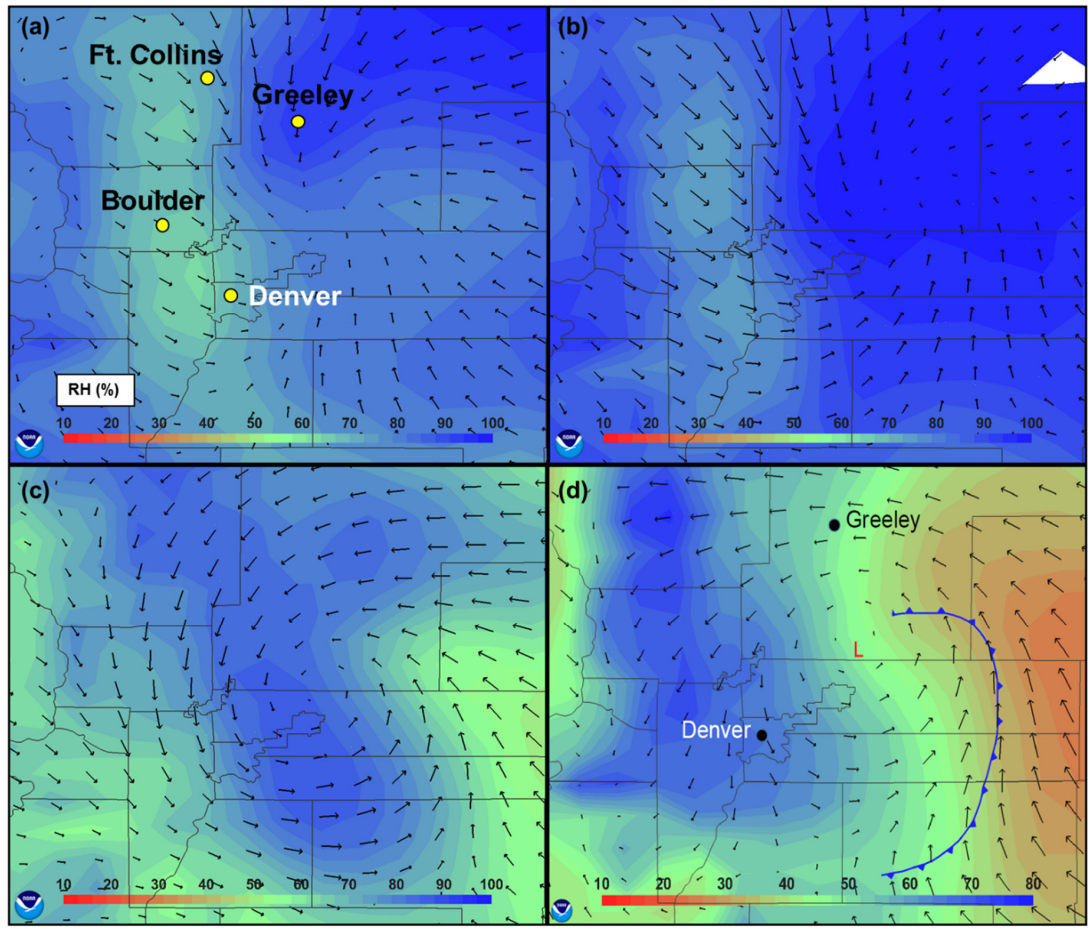

Figure 3. RAP model analysis runs at $13 \mathrm{~km}$ resolution for the Denver Cyclone on Sunday, 27 July 2014, at (a) 10:00 UTC (03:00 MST), (b) 12:00 UTC (05:00 MST), (c) 15:00 UTC (08:00 MST), and (d) 18:00 UTC (11:00 MST). The blue line represents a convergence zone or front associated with the cyclone. Arrows show surface wind vectors, while the color scale represents surface RH. 
synoptic-scale winds leading to a hybrid pattern. Such a pattern is apparent for the daytime winds plotted in Figs. 2b, d and $\mathrm{S} 2 \mathrm{~b}$, d, where thermally driven upslope flow was more apparent over the higher terrain to the west and synopticscale flows had a greater influence over the plains. Shortrange return flows which can be formed by various mesoscale phenomena (Reddy et al., 1995), including the Denver Cyclone, can occur any time of the day and lead to a shift in direction of the winds with an easterly component. These can draw the Platte Valley air masses uphill and back over the greater Denver metropolitan area, enhancing the mixing of older and new emissions (Neff, 1989).

Pronounced and fully developed surface mesoscale circulations of the Denver Cyclone were observed on Sunday, 27 July 2014. Surface wind patterns and RH in Fig. 3a$\mathrm{d}$ display the development of the Denver Cyclone between 10:00 and 18:00 UTC (03:00 and 11:00 MST, correspondingly) on 27 July. Figure 3a depicts the early stages of the cyclone with converging flows and the beginnings of a counterclockwise circulation pattern centered to the northeast of Denver. As seen in Fig. 3b, by 12:00 UTC (05:00 MST on 27 July), RH was beginning to peak on the western or return flow side of the cyclone center, which was still to the northeast of Denver. This northeasterly-northerly-northwesterly return flow on the western side of the cyclone transported cool and moist air masses from the Platte Valley north of Denver towards the urban core as the cyclone matured. As shown in Fig. S3b-d, air masses with higher water content were advected westward by easterly winds, ahead of the intensifying low-pressure system that was developed by 18:00 UTC (11:00 MST on 27 July). A well-organized, welldefined cyclone circulation continued with its center in the same location at 18:00 UTC (11:00 MST on 27 July) with a warm, dry inflow to the east of the center and convergence line and a cool, humid wraparound flow on the west side of the Denver Cyclone (Fig. 3d).

Various tracers were considered in the Weather Research and Forecasting Model (WRF) to predict the distribution of emitted pollutants in the Front Range at a horizontal resolution of $3 \mathrm{~km} \times 3 \mathrm{~km}$. The model was initialized with the Global Forecast System (GFS) at $0.5^{\circ} \times 0.5^{\circ}$ resolution and at 00:00 UTC (17:00 MST, on previous day) and 12:00 UTC (05:00 MST) to produce $48 \mathrm{~h}$ forecasts. Figure S4a-f of the supplementary material presents the distribution of the $\mathrm{O} \& \mathrm{G}$ tracer on 27 July. These forecasting results represent the cyclone development on 27 July well, with the surface winds reflecting the counterclockwise circulations (NE to $\mathrm{SW})$ though the cyclone core was predicted to be further northeast of the Denver urban area. In this case, the model was able to predict the cyclone episode and transport of emission tracers $24 \mathrm{~h}$ in advance, driving the motivation for carrying out aircraft measurements during this event. In the next sections, the impacts of this synoptic-scale recirculation flow on pollutant distribution in the region are discussed.

\subsection{Spatial distribution of trace gases and aerosols}

The meteorological conditions described above are critical when considering atmospheric aerosol formation, evolution, and spatial distribution. Figure $4 \mathrm{a}-\mathrm{f}$ show the spatial distribution of ammonia $\left(\mathrm{NH}_{3}\right)$, ethane $\left(\mathrm{C}_{2} \mathrm{H}_{6}\right)$, and carbon monoxide (CO), i.e., tracers for agricultural and CAFOs, O\& G, and combustion and vehicular emissions on non-cyclone and cyclone days. Additionally, spatial representations of nitrogen oxides $\left(\mathrm{NO}_{x}=\mathrm{NO}+\mathrm{NO}_{2}\right)$, secondary gaseous pollutants $\left(\mathrm{O}_{3}\right.$ and PAN), and major aerosol components (OA, $\mathrm{NO}_{3}^{-}$, and $\mathrm{SO}_{4}^{2-}$ ) during non-cyclone and cyclone days are shown in Figs. 5 and 6.

Consistent with the meteorological conditions presented above, there is a contrast in the spatial distribution and separation of pollutants during the non-cyclone and cyclone situations. Westward transport of emissions was seen on the noncyclone (26 July, 2-3 August) days with the separation of pollutants in the northern and southern latitudes as depicted in Fig. $4 \mathrm{a}$ and $\mathrm{b}$ for $\mathrm{C}_{2} \mathrm{H}_{6}$ and $\mathrm{NH}_{3}$. Ethane observations indicate that emissions from $\mathrm{O} \& \mathrm{G}$, which are concentrated northeast of Denver, were mostly localized downwind and to the west of the sources during the non-cyclone periods. $\mathrm{NH}_{3}$ point sources are predominantly concentrated in areas near Fort Collins and Greeley where a significantly large number of animal and livestock feeding operations reside. Nitrate production has both an urban and agricultural component due to oxidation of $\mathrm{NO}_{x}$ to $\mathrm{HNO}_{3}$, the subsequent reaction of $\mathrm{HNO}_{3}$ with gas phase $\mathrm{NH}_{3}$, and the partitioning of ammonium nitrate into the aerosol phase. These interactions will be explored further with the ISORROPIA II model in Sect. 3.5. The cyclonic circulation on 27-28 July transported emissions from point sources in NFR down to DM (e.g., $\mathrm{C}_{2} \mathrm{H}_{6}$ and $\mathrm{NH}_{3}$ in Fig. 4d and e) and concentrated secondary photochemical products (e.g., $\mathrm{O}_{3}$, PAN, OA, and $\mathrm{NO}_{3}^{-}$in Figs. 5e, $\mathrm{f}$ and $6 \mathrm{~d}, \mathrm{e})$ in and around the Denver/Boulder metropolitan area compared to the northern counties (Fig. $4 \mathrm{~d}$ and e). Regional trends in trace gas and aerosol concentrations during cyclone and non-cyclone periods are discussed in Sect. 3.3.

\subsection{Trends in trace gas and aerosol concentrations}

Variations in the spatial distribution of pollutants during the cyclone and non-cyclone events highlight the impacts of numerous sources and meteorology on air quality and aerosol formation within the Front Range. Here, we evaluate measurements of several auxiliary gases and aerosol chemical composition to gain insights on the influence of atmospheric dynamics on aerosol formation in the three regions of interest in the Front Range.

\subsubsection{Gas phase tracers}

As discussed in Sect. 3.2., depending on the presence or absence of the cyclone, trace gases were transported and dis- 

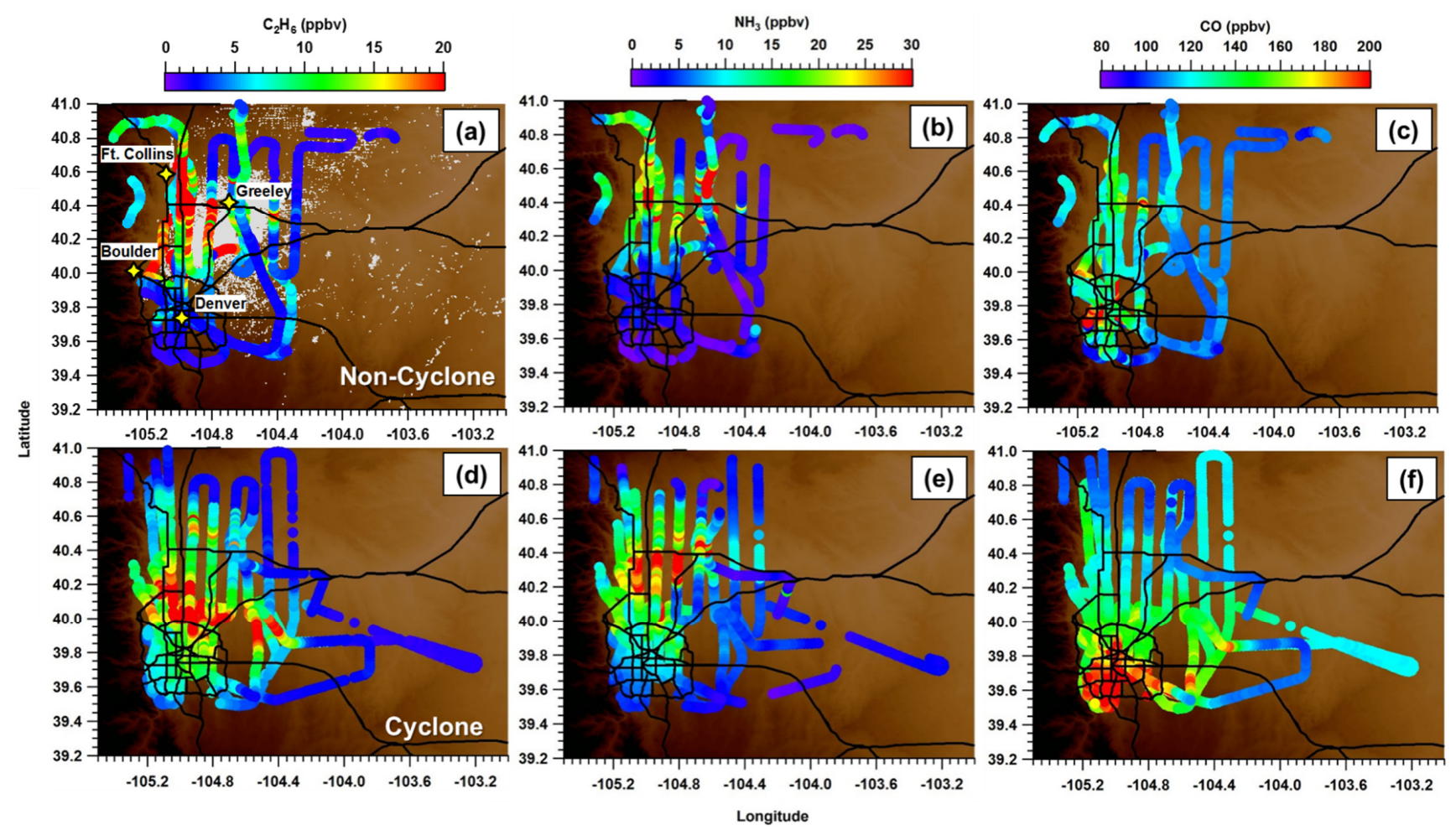

Figure 4. Spatial distribution maps along the $\mathrm{C} 130$ flight track of ethane $\left(\mathrm{C}_{2} \mathrm{H}_{6}\right)$, ammonia $\left(\mathrm{NH}_{3}\right)$, and carbon monoxide $(\mathrm{CO})$ in the Colorado Front Range during non-cyclone (a-c) and cyclone episodes (d-f). Major highways are shown with black lines, and grey markers in (a) represent the location of active oil and gas wells in the region with data available from the Colorado Oil and Gas Conservative Commission.

persed differently in the region. In Fig. 7, the statistical distribution of several gas phase tracers, namely $\mathrm{NH}_{3}, \mathrm{C}_{2} \mathrm{H}_{6}$, the sum of $\mathrm{C}_{6}-\mathrm{C}_{9}$ aromatics, and $\mathrm{CO}$ measured in the In-Flow, NFR, and DM during the non-cyclone and cyclone periods are shown. Volatile organic compounds (VOCs) play important roles as atmospheric precursors to ground-level ozone and SOA (Turpin and Huntzicker, 1995; Song et al., 2005; Volkamer et al., 2006; Kroll and Seinfeld, 2008; Hallquist et al., 2009; von Stackelberg et al., 2013; Riva et al., 2015). The aromatics highlighted in Fig. 7 represent a subset of the measured VOCs, typically found in O \& G and vehicular emissions, that are known to form SOA (Ng et al., 2007; Gentner et al., 2012).

During the non-cyclone periods, the mean mixing ratio of $\mathrm{NH}_{3}$ (Fig. 7a) in In-Flow and NFR areas was $13 \pm 11 \mathrm{ppbv}$, while a significantly lower mean mixing ratio $(3.8 \pm 3.6 \mathrm{ppbv})$ was observed in DM, owing to the high concentration of major ammonia point sources in the northeastern parts of the Front Range. Additionally, the mean mixing ratio of $\mathrm{C}_{2} \mathrm{H}_{6}$ (Fig. 7b) was higher by a factor of 2-2.6 in NFR (11.9 $\pm 8.0 \mathrm{ppbv})$ compared to the In-Flow $(4.6 \pm 4.1 \mathrm{ppbv})$ and DM $(6.0 \pm 7.8 \mathrm{ppbv})$, due to substantial density of $\mathrm{O} \& \mathrm{G}$ exploration activities in NFR. For $\sum \mathrm{C}_{6-}$ $\mathrm{C}_{9}$ aromatics (Fig. $7 \mathrm{c}$ ), mixing ratios were higher over DM $(\sim 0.4-0.5 \mathrm{ppbv})$ compared to NFR $(\sim 0.15-0.3 \mathrm{ppbv})$ dur- ing both cyclone and non-cyclone events. This is in contrast to the pattern observed for $\mathrm{C}_{2} \mathrm{H}_{6}$, suggesting that the emission sources of $\mathrm{C}_{6}-\mathrm{C}_{9}$ aromatics are more concentrated in DM. Similar to $\sum \mathrm{C}_{6}-\mathrm{C}_{9}$ aromatics and consistent with combustion processes being the dominant source of aromatics and $\mathrm{CO}$, mean mixing ratios of $\mathrm{CO}$ (Fig. 7d) were highest over DM during non-cyclone and cyclone periods.

Mean mixing ratios of $\mathrm{CO}$ over DM during the cyclone were $144 \pm 23 \mathrm{ppbv}$ compared to $110 \pm 8.7 \mathrm{ppbv}$ in In-Flow and $114 \pm 12 \mathrm{ppbv}$ in NFR. Additionally, mean values of CO and $\mathrm{C}_{2} \mathrm{H}_{6}$ in DM increased during the cyclone events compared to non-cyclone days (Fig. 7b and d). Since vehicular sources of $\mathrm{CO}$ are concentrated in DM, the slight increase in $\mathrm{CO}$ over DM during the cyclone was likely due to changes in the background $\mathrm{CO}$ in the region and a shallower morning boundary layer on 27-28 July. However, the increase in $\mathrm{C}_{2} \mathrm{H}_{6}$ could be due to the release of emissions into a shallower morning boundary layer on cyclone days, the cyclonic mixing of air masses from northern latitudes with higher emissions of $\mathrm{C}_{2} \mathrm{H}_{6}$ from $\mathrm{O} \& \mathrm{G}$ operations, or a combination of these two phenomena. The observed increase in the mean $\mathrm{C}_{2} \mathrm{H}_{6}$ mixing ratio in DM during the cyclone compared to the non-cyclone days was $10.2 \pm 6.2 \mathrm{ppbv}$ vs. $6.0 \pm 7.8 \mathrm{ppbv}$, respectively. To better understand the influence of $\mathrm{O} \& \mathrm{G}$ operations over DM during the cyclone, 

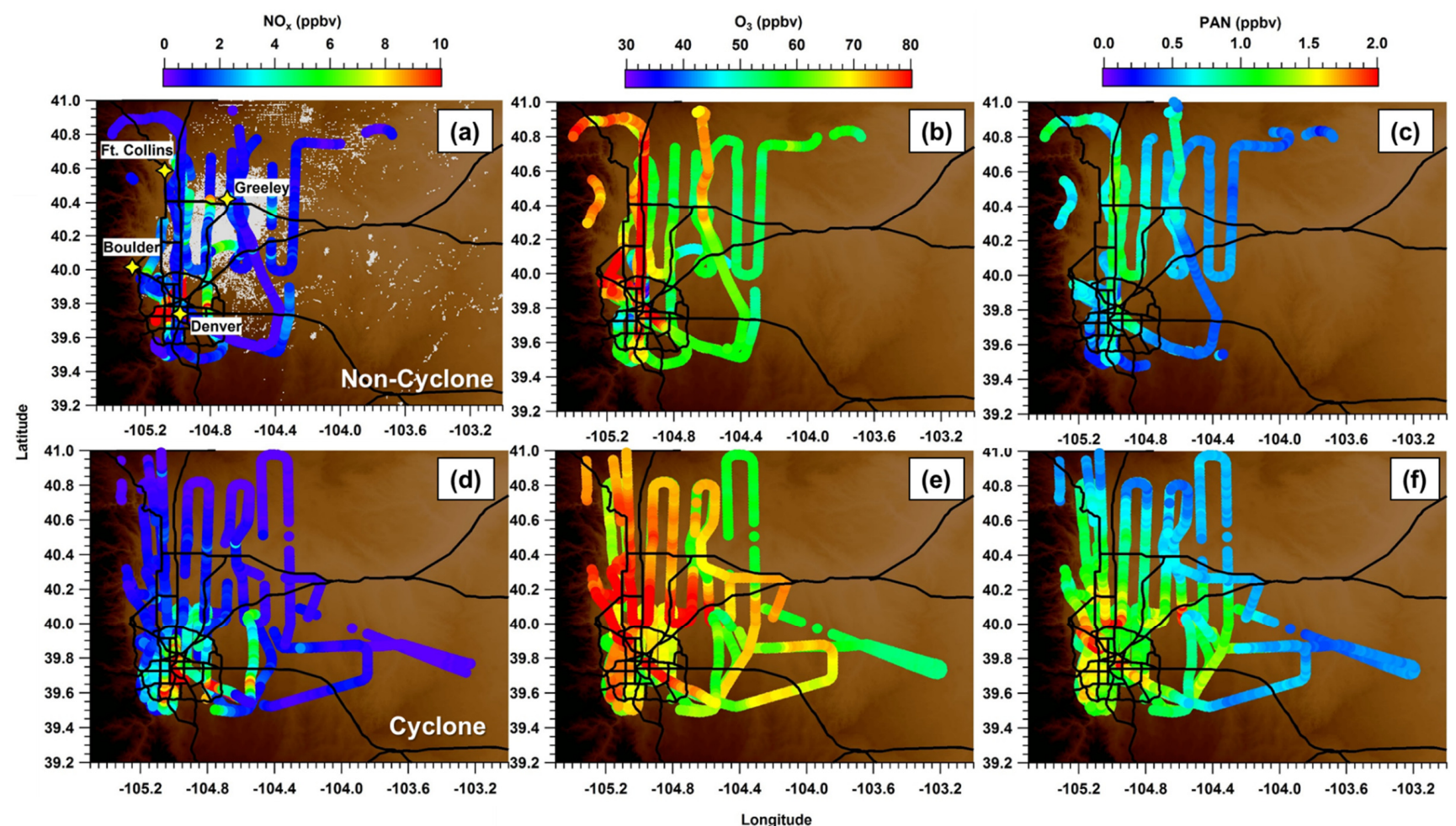

Figure 5. Spatial distribution maps along the $\mathrm{C} 130$ flight track of $\mathrm{NO}_{x}\left[\mathrm{NO}+\mathrm{NO}_{2}\right]$, ozone $\left(\mathrm{O}_{3}\right)$, and peroxyacetylnitrate $(\mathrm{PAN})$ in the Colorado Front Range during the non-cyclone (a-c) and cyclone episodes (d-f). Major highways are shown with black lines, and grey markers in (a) represent the location of active oil and gas wells in the region with data available from the Colorado Oil and Gas Conservative Commission.

we examined the ratio of $i$-pentane to $n$-pentane since $\mathrm{O} \& \mathrm{G}$ emissions show a characteristic ratio in the range of $0.8-1.2$ (Gilman et al., 2013; Swarthout et al., 2013; Thompson et al., 2014; Halliday et al., 2016) in contrast to urban sources predominately impacted by vehicular emissions, which typically have a higher ratio between 2 and 3 (Broderick and Marnane, 2002; Baker et al., 2008). Figure 7e represents the statistical analysis of the $i$-pentane to $n$-pentane ratio in the threes study regions. Non-cyclone days show a significant urban source of pentanes in DM compared to NFR. During the cyclone, a minor decrease in the ratio was observed in NFR, whereas the ratio decreased substantially in DM to values close to those in NFR. These observations suggest that the significant increase in the $\mathrm{C}_{2} \mathrm{H}_{6}$ mixing ratio observed over DM during the cyclone cannot be solely explained by $\mathrm{BL}$ height differences but is rather driven by transport of $\mathrm{O} \& \mathrm{G}-$ impacted and $\mathrm{C}_{2} \mathrm{H}_{6}$-rich air masses from NFR into DM. Similarly, cyclonic transport of $\mathrm{NH}_{3}$ from NFR to DM resulted in a $30 \%$ increase in average $\mathrm{NH}_{3}$ mixing ratios over $\mathrm{DM}$, from $3.8 \pm 2.8$ to $8.8 \pm 3.9 \mathrm{ppbv}$, while the mixing ratios in In-Flow and NFR did not change significantly.

\subsubsection{NR-aerosol composition}

Average boundary layer values of non-refractory submicron aerosol (NR-PM $)_{1}$ composition in the Front Range in both non-cyclone and cyclone episodes are shown in Fig. 8, with the exclusion of $\mathrm{Cl}^{-}$due to average mass loadings that were below its average detection limit of $0.19 \mu \mathrm{g} \mathrm{s} \mathrm{m}^{-3}$. Throughout the non-cyclone period, the average mass concentrations of NR-PM 1 aerosols were consistently lower in all three regions, by a factor of $\sim 2.5$. Additionally, the NR aerosol was dominated by OA $\left(75 \%, 3.25 \pm 1.45 \mu \mathrm{g} \mathrm{s} \mathrm{m}^{-3}\right)$, followed by sulfate $\left(13 \%, 0.58 \pm 0.27 \mu \mathrm{g} \mathrm{s} \mathrm{m}^{-3}\right)$, ammonium $\left(6 \%, 0.28 \pm 0.88 \mu \mathrm{g} \mathrm{s} \mathrm{m}^{-3}\right)$, and nitrate $(6 \%$, $0.26 \pm 0.27 \mu \mathrm{g} \mathrm{s} \mathrm{m}^{-3}$ ) (Fig. 8a). During the cyclone events, OA still dominated NR-PM 1 aerosol composition but with a lower fraction $(60 \%)$, while the contribution of nitrate, and correspondingly ammonium, increased to 16 and $11 \%$, respectively. It is worth comparing the current measurements with those made during NFRAQS (summer 1996). The overall composition of NR aerosols was similar in 1996, with OA as the dominant species present. However, assuming a conservative organic matter mass to organic carbon ratio of 1.7 (Turpin and Lim, 2001; Aiken et al., 2008), OA mass of $\mathrm{PM}_{2.5}$ during 1996 was estimated to be $7.14 \mu \mathrm{g} \mathrm{m}^{-3}$, which is more than a factor of 2 higher than the average non-cyclone 

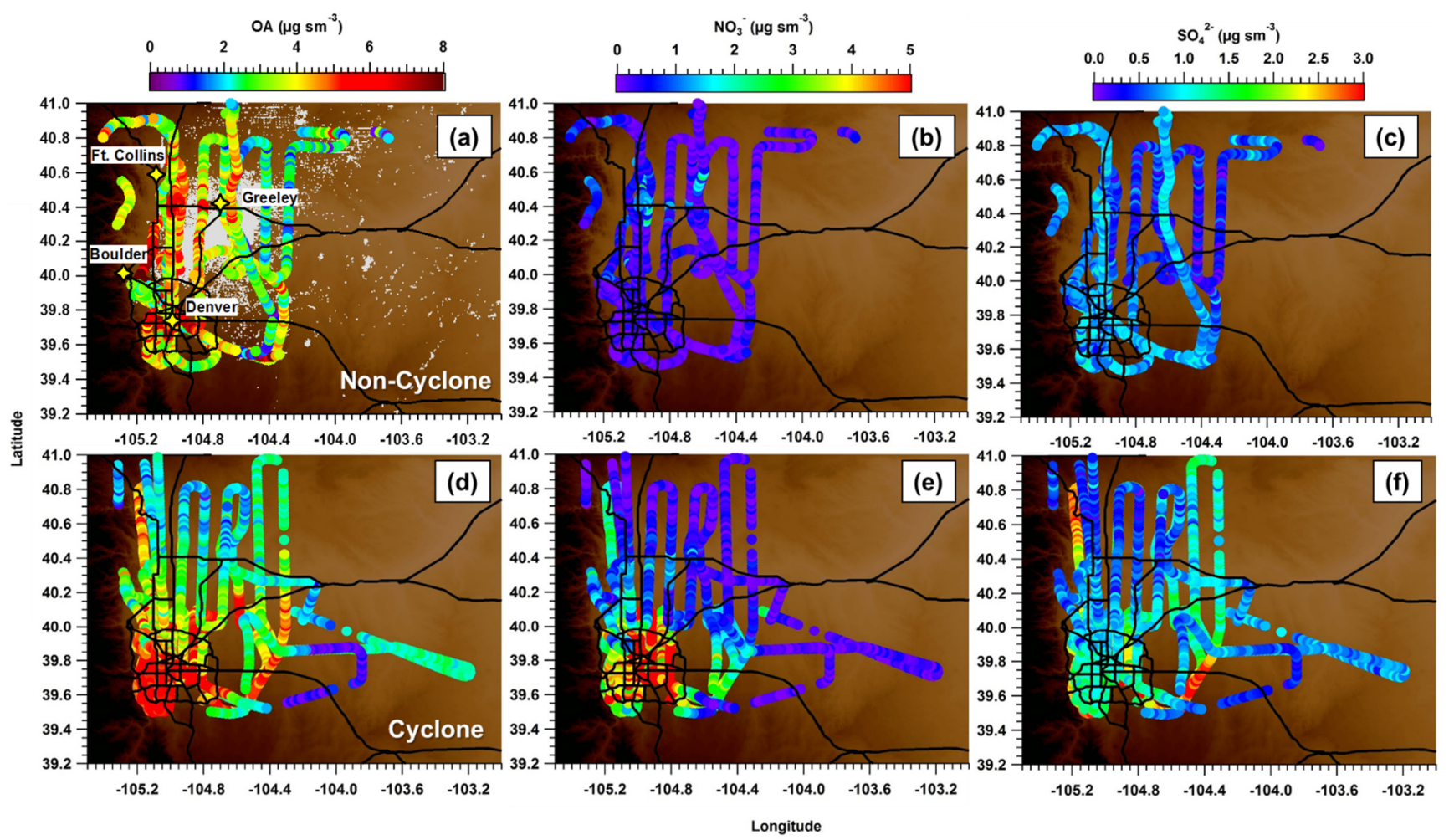

Figure 6. Spatial distribution maps along the $\mathrm{C} 130$ flight track of aerosol species $\left(\mathrm{OA}, \mathrm{NO}_{3}^{-}\right.$, and $\left.\mathrm{SO}_{4}^{2-}\right)$ in the Colorado Front $\mathrm{Range}$ during the non-cyclone (a-c) and cyclone episodes (d-f). Major highways are shown with black lines, and grey markers in (a) represent the location of active oil and gas wells in the region with data available from the Colorado Oil and Gas Conservative Commission.

OA concentration during FRAPPÉ. Additionally, average concentrations of sulfate and nitrate during the NFRAQS (summer 1996) were factors of $\sim 2-4$ higher than those on the non-cyclone days of FRAPPÉ. Note that comparison of 1996 vs. 2014 data is not exact due to a higher $\left(\mathrm{PM}_{2.5}\right)$ size cut of the 1996 measurements. Wintertime measurements during the Metro Denver Brown Cloud Air Pollution Study indicated that aerosol composition was again dominated by OA $(68 \%)$, followed by sulfate $(14 \%)$, nitrate $(10 \%)$, ammonium $(8 \%)$, and chloride $(<1 \%)$.

Shown in Fig. S5 are additional NR-PM 1 compositional pie charts for individual regions (In-Flow, NFR, DM) during the non-cyclone and cyclone periods of FRAPPÉ. As noted previously, OA was the single dominant species in all three regions. Relative NR-PM 1 composition in In-Flow was most similar between the non-cyclone and cyclone periods, whereas the relative contribution of $\mathrm{NO}_{3}^{-}$increased during the cyclone period in NFR and DM at the expense of OA. Represented in Fig. 9a-c are the observed trends in the NR$\mathrm{PM}_{1}$ aerosol concentrations $\left(\mathrm{OA}, \mathrm{NO}_{3}^{-}\right.$, and $\left.\mathrm{SO}_{4}^{2-}\right)$ measured in In-Flow, NFR, and DM during the non-cyclone and cyclone periods. Mass concentrations were consistently lower in non-cyclone periods for all the measured aerosol species and within all three regions. On average, there was a $40 \%$ increase in average OA (Fig. 9a) on cyclone days across all three regions, while the increase during the cyclone episode was up to $\sim 80 \%$ for DM - an important consideration for air quality measures. During the non-cyclone days, average $\mathrm{NO}_{3}^{-}$was slightly higher in NFR $\left(0.43 \pm 0.39 \mu \mathrm{g} \mathrm{s} \mathrm{m}^{-3}\right)$ compared to DM $\left(0.20 \pm 0.20 \mu \mathrm{g} \mathrm{s}^{-3}\right)$, whereas during the cyclone episode, average $\mathrm{NO}_{3}^{-}$was a factor of 3.3 higher in DM $\left(2.21 \pm 1.44 \mu \mathrm{g} \mathrm{s} \mathrm{m}^{-3}\right)$ compared to NFR $\left(0.67 \pm 0.54 \mu \mathrm{g} \mathrm{s} \mathrm{m}^{-3}\right)$. Overall, average $\mathrm{SO}_{4}^{2-}$ (Fig. 9c) mass concentrations also displayed a 2 -fold increase across all regions during the cyclone period. Consistent with the observations for $\mathrm{NH}_{3}$ and $\mathrm{C}_{2} \mathrm{H}_{6}$, significantly larger increases in aerosol mass concentrations during the cyclone period were observed in DM compared to NFR, suggesting that mass concentrations during the cyclone were only slightly impacted by a shallower BL. Instead, transport of precursors and possibly aerosols from northern latitudes towards DM was the main driver for the observed increased concentrations in DM. The fact that the highest aerosol concentrations during the cyclone period were observed in the greater DM underscores the importance of the impact of local meteorology on air quality in an area with a large population density. 


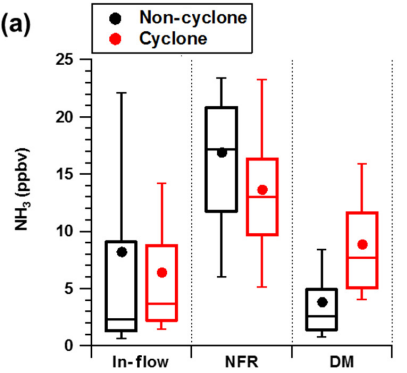

(b)

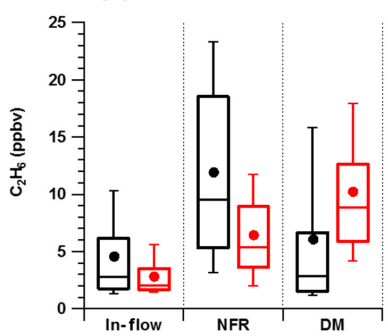

(c)
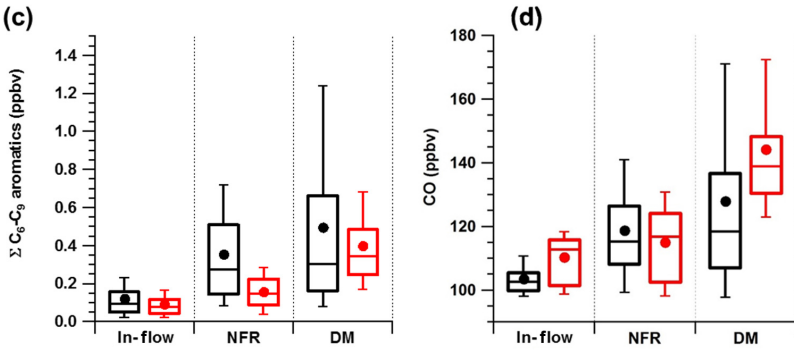

(e)

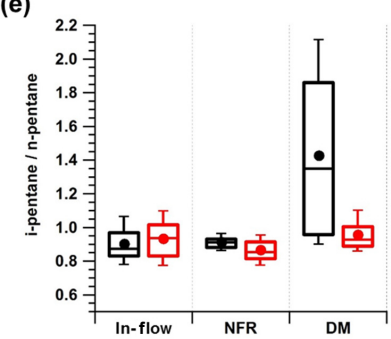

(a) Non-cyclone

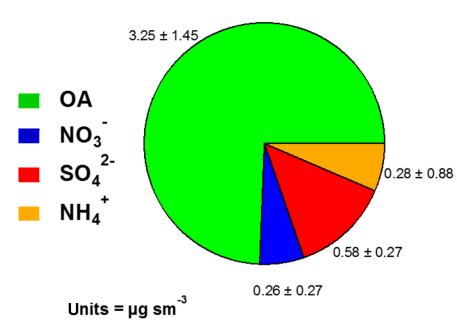

(b) Cyclone

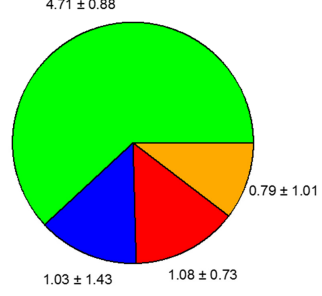

Figure 8. Average chemical composition of mAMS species in all regions during (a) non-cyclone and (b) cyclone events. Chloride $\left(\mathrm{Cl}^{-}\right)$, not shown, was below the instrument detection limit.

clone events, $\mathrm{NO}_{x} / \mathrm{NO}_{y}$ values were similar in NFR, while the average values decreased by $37 \%$ in the In-Flow and DM regions, indicating further the extent of photochemical processing of $\mathrm{NO}_{x}$-containing air masses in these regions.

One caveat in this analysis may be the impact of lower $\mathrm{NO}_{x}$ emissions during the weekends (26-27 July), resulting in faster photochemistry and more secondary formation of $\mathrm{NO}_{y}$ species and ozone. Several studies in high-density population areas such as in Los Angeles have investigated the weekend effect on ambient ozone (Pollack et al., 2012; Warneke et al., 2013). These studies demonstrate that the higher ozone mixing ratios observed on weekends compared to weekdays are due to the significant weekend decrease in $\mathrm{NO}_{x}$ emissions from diesel vehicles and a marginal, if any, decrease in the emissions of non-methane hydrocarbons from gasoline vehicles, resulting in faster photochemistry, less ozone loss due to $\mathrm{NO}_{x}$ titration, and more rapid ozone production (Pollack et al., 2012; Warneke et al., 2013). To examine changes in the weekend $\mathrm{NO}_{x}$ emissions in the Front Range, we utilized the $\mathrm{NO}_{y}$ and $\mathrm{CO}$ data measured in the boundary layer onboard the NASA P-3 aircraft during DISCOVER-AQ, which included data from a total of 8 weekday and 4 weekend flights from 17 July to 10 August. During the weekends, the $\mathrm{NO}_{x}$ to $\mathrm{CO}$ enhancement ratio, determined by error-weighted ( $5 \%$ for $\mathrm{NO}_{x}$ and $2 \%$ for $\mathrm{CO}$ ) orthogonaldistance regression (ODR) fits, was lower by a factor of $\sim 1.8$ compared to weekdays (Fig. 11), which is in close agreement with observations made through aircraft measurements in the Los Angeles basin (Pollack et al., 2012), indicating a similar decrease in weekend diesel traffic in the Front Range as in Los Angeles.

In addition to the weekend change in photochemical processing of $\mathrm{NO}_{x}$, the meteorological influence of a cyclone may also impact ozone, and possibly other secondary species, formation. Reddy and Pfister (2016) indicate that the Denver Cyclone is one of many potential terrain-related mechanism for limiting area-wide dispersion of $\mathrm{O}_{3}$ and its precursors. Trace gas spatial distribution maps, provided in Figs. 4 and 5, indeed indicated strong accumulation of secondary pollutants during the cyclonic event. Further analysis 

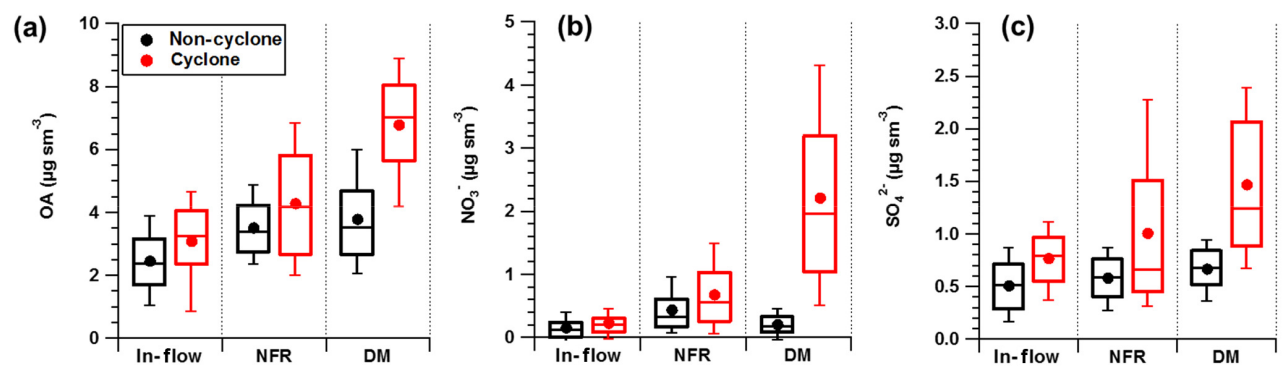

Figure 9. Statistical representation of the distribution of the mass concentrations of aerosol species $\left(\mathrm{OA}, \mathrm{NO}_{3}^{-}, \mathrm{SO}_{4}^{2-}\right)$ within the three study regions. The box and whiskers indicate 10th, 25th, 75th, and 90th percentiles, while the solid lines and circles mark the median and mean values, respectively.

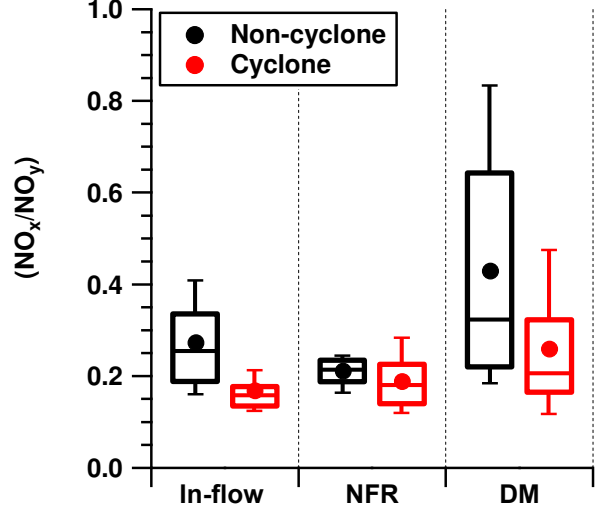

Figure 10. Statistical representation of the distribution of the mixing ratios of $\mathrm{NO}_{x} / \mathrm{NO}_{y}$ within the three study regions. The box and whiskers indicate 10th, 25th, 75th, and 90th percentiles, while the solid lines and circles mark the median and mean values, respectively.

to investigate the impact of the cyclone on ozone formation in the Front Range requires chemical box or regional modeling and is beyond the scope of this paper.

Evolution of OA through photochemical aging during the cyclone and non-cyclone periods was studied in air masses with $\mathrm{NO}_{x} / \mathrm{NO}_{y}<0.5$, which represent intermediate to strongly processed $\mathrm{NO}_{x}$-containing plumes. As the plumes age, an increase in the observed $\triangle \mathrm{OA} / \triangle \mathrm{CO}$ ratio suggests SOA production. In this analysis, we evaluated air masses sampled over DM to determine the extent of photochemical aging effects on Denver's local air quality. The error-weighted (30\% uncertainty in OA, $3 \%$ uncertainty in $\mathrm{CO})$ linear ODR fits to the scatterplots of measured OA against background subtracted $\mathrm{CO}$ were obtained, with the slopes representing the ratios of $\triangle \mathrm{OA} / \triangle \mathrm{CO}$ (Fig. 12). Background $\mathrm{CO}$ values (90 and $110 \mathrm{ppbv}$ during the non-cyclone and cyclone days) were based on the modes of the Gaussian curves fitted to the frequency distribution plots of CO. Uncertainties in the slopes represent the propagated uncertainties, i.e., the square root of the quadric sum of the rela-

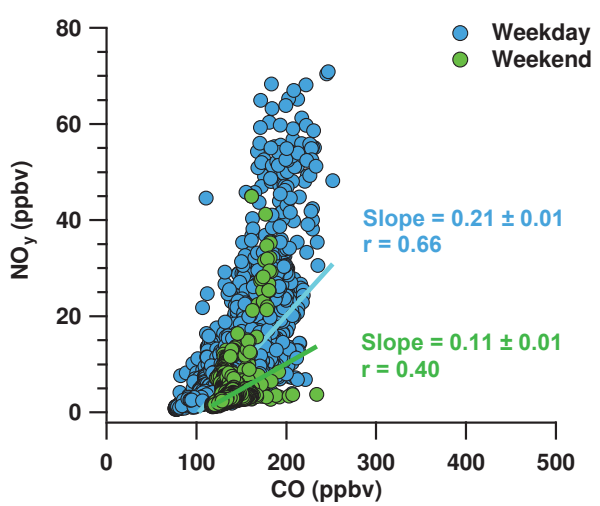

Figure 11. Scatterplot of measured $\mathrm{NO}_{y}$ vs. $\mathrm{CO}$ using aircraft data from the DISCOVER-AQ P-3 flights. Weekday (blue dots, 8 combined days) and weekend (green dots, 4 combined days). Inferred slopes are derived from ODR error-weighted (5\% $\left.\mathrm{NO}_{y}, 2 \% \mathrm{CO}\right)$ fits.

tive uncertainties in the ODR fit, OA concentration, and $\mathrm{CO}$ mixing ratio. The average cyclone $\triangle \mathrm{OA} / \triangle \mathrm{CO}$ values were higher $\left(0.060 \pm 0.018 \mu \mathrm{g} \mathrm{s} \mathrm{m}^{-3} \mathrm{ppbv}^{-1}, r=0.56\right)$ compared to the non-cyclone periods $\left(0.049 \pm 0.019 \mu \mathrm{g} \mathrm{s} \mathrm{m}^{-3} \mathrm{ppbv}^{-1}\right.$, $r=0.45$ ), although not significantly considering the uncertainties associated with the fits. However, a significantly higher intercept of the fit was obtained on the cyclone days $\left(5.03 \pm 1.52 \mu \mathrm{g} \mathrm{s} \mathrm{m}^{-3}\right)$ compared to the non-cyclone days $\left(2.05 \pm 0.69 \mu \mathrm{g} \mathrm{s} \mathrm{m}^{-3}\right)$, indicating transport of additional OA relative to $\mathrm{CO}$ from the northern latitudes towards DM during the cyclone events. From an air quality standpoint, such enhancement in total OA concentration is significant since it is comparable in magnitude to the average OA over DM during the typical non-cyclone summer days.

\subsection{Aerosol nitrate production}

We assess the regional formation of aerosol nitrate through comparisons of aerosol nitrate fraction $\left(f_{\mathrm{NO}_{3}}=\mathrm{NO}_{3}^{-} /\left(\mathrm{NO}_{3}^{-}+\mathrm{HNO}_{3}\right)\right)$ in the In-Flow, NFR, and DM regions with and without the cyclone influence 


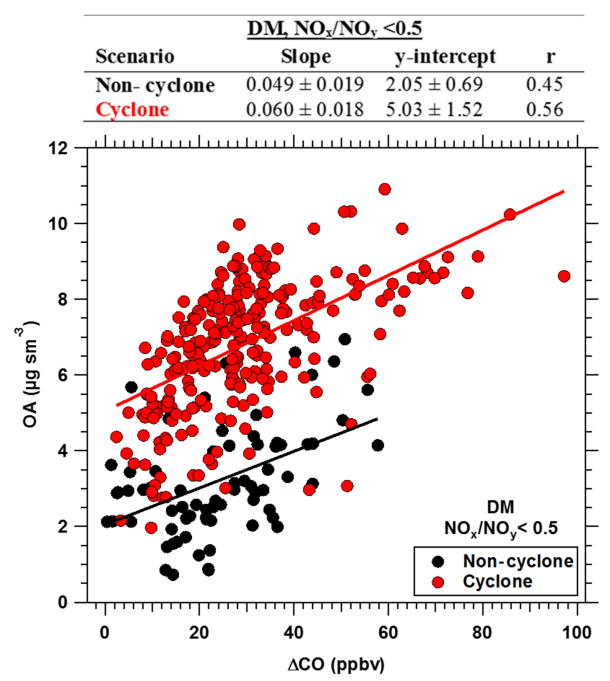

Figure 12. Scatterplot of OA $\left(\mu \mathrm{g} \mathrm{s} \mathrm{m}^{-3}\right)$ vs. $\Delta \mathrm{CO}$ (ppbv) under the most aged air masses $\left(\mathrm{NO}_{x} / \mathrm{NO}_{y}<0.5\right)$ in $\mathrm{DM}$ for non-cyclone (black) and cyclone (red) days. Slope and intercept values are based on the ODR error-weighted (30\% OA, $3 \% \mathrm{CO}$ ) fits, while the correlation coefficients are based on the linear least-squared regression fits.

(Fig. 13a). Low $f_{\mathrm{NO}_{3}}$ values observed in NFR and DM regions during the non-cyclone days indicate that nitric acid was predominantly present in the gas phase. In contrast, higher $f_{\mathrm{NO}_{3}}$ values observed during the cyclone suggest increased partitioning of nitric acid to the condensed phase. As noted earlier, environmental factors including relative humidity, temperature, and atmospheric dynamics play important roles in the formation of aerosol nitrate (Stelson et al., 1979; Stelson and Seinfeld, 1982; Watson, 2002). Slightly lower temperature and increased $\mathrm{RH}$ were observed in NFR and DM during the cyclone period (Table 1). Higher RH may enhance formation of nitrate aerosols by promoting aqueous and heterogeneous phase reactions and increasing the equilibrium partitioning of gas phase $\mathrm{NH}_{3}$ and $\mathrm{HNO}_{3}$ to the condensed particle phase (Stelson et al., 1979; Stelson and Seinfeld, 1982; Volkamer et al., 2006; Na et al., 2007; von Hessberg et al., 2009). Moreover, local meteorology during the cyclone period, facilitating transport of $\mathrm{NH}_{3}$ from the nearby feedlots in NFR to DM (Sect. 3.3.1, Fig. 4b and e), could have favored equilibrium partitioning of nitric acid to the aerosol phase due to abundance of gas phase $\mathrm{NH}_{3}$.

To further investigate the role of atmospheric conditions and mixing patterns in aerosol nitrate formation during the cyclone days, nitrate partitioning was evaluated by ISORROPIA II (Fountoukis and Nenes, 2007) model calculations, described in Sect. 2.4. The predicted partitioning results, summarized in Table S1 in the Supplement and Fig. 13a are in reasonable agreement with the observed $f_{\mathrm{NO}_{3}}$ values on non-cyclone and cyclone days. Over DM, the model pre- (a)

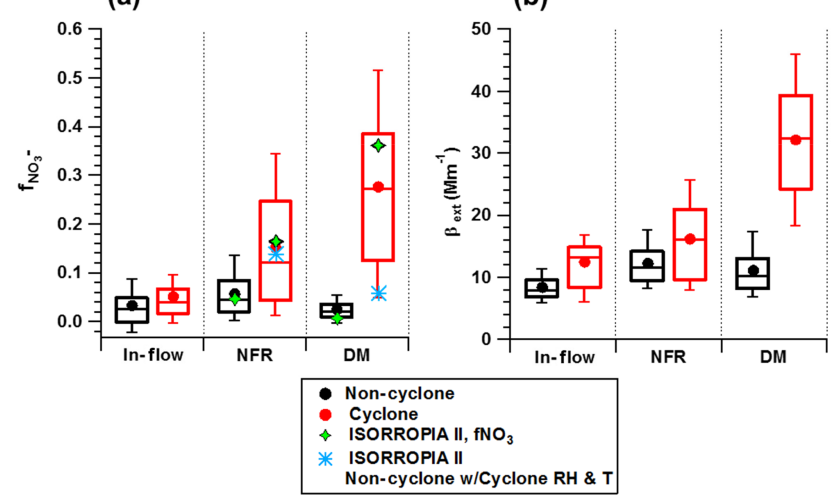

Figure 13. Statistical representation of the distribution of (a) aerosol nitrate fraction $\left(f \mathrm{NO}_{3}=\mathrm{NO}_{3}^{-} /\left[\mathrm{NO}_{3}^{-}+\mathrm{HNO}_{3}\right]\right.$ and (b) aerosol optical extinction within the three studied regions during non-cyclone and cyclone periods. The box and whiskers indicate 10th, 25th, 75th, and 90th percentiles, while the solid lines and circles mark the median and mean values, respectively. Modeled $f \mathrm{NO}_{3}$ values with actual inputs of chemical composition and $T$ and $\mathrm{RH}$ are shown with green diamonds, while the predicted values with the non-cyclone composition and cyclone $T$ and RH are shown with blue stars.

dicted $24 \%$ more nitrate existing in the aerosol phase compared to mean values based on the measurements; however, the predicted $f_{\mathrm{NO}_{3}}$ is still within the limits of variability of the observed $f_{\mathrm{NO}_{3}}$. To evaluate the influence of $\mathrm{RH}$ and $T$ on aerosol nitrate formation, we considered model input variables based on the non-cyclone concentrations, while prescribing the higher $\mathrm{RH}$ and lower $T$ values representing conditions of the cyclone period (Table S1). In this case, the model predicted similar $f_{\mathrm{NO}_{3}}$ values in NFR and significantly lower $f_{\mathrm{NO}_{3}}$ over DM compared to the measurements, indicating that the observed higher partitioning of nitrate to the aerosol phase during the cyclone events was not mainly driven by changes in ambient $T$ and $\mathrm{RH}$, but rather it was due to increased availability of $\mathrm{NH}_{3}$ over $\mathrm{DM}$ with the cyclonic transport from NFR.

We further evaluated the influence of sulfate concentrations and ambient RH to understand how chemical composition and environmental changes in DM could impact nitrate partitioning between gas and aerosol phases (Table S2). While keeping $T, \mathrm{RH}$, gas phase ammonia, and ammonium associated with nitrate at the same level as in the baseline (i.e., observations on cyclone days over DM), the absence of aerosol sulfate results in a drastic increase in $f_{\mathrm{NO}_{3}}$, with almost all of the nitric acid partitioning to the aerosol phase. This result indicates that background aerosol sulfate concentrations have a strong effect on equilibrium partitioning of nitric acid. Next, we evaluated the influence of RH, keeping all other variables the same as in the baseline. Increasing $\mathrm{RH}$ from 64 to $85 \%$ resulted in an increase in $f_{\mathrm{NO}_{3}}$ of 0.36 to 0.74 , while decreasing RH to $35 \%$ decreased $f_{\mathrm{NO}_{3}}$ 
(a)

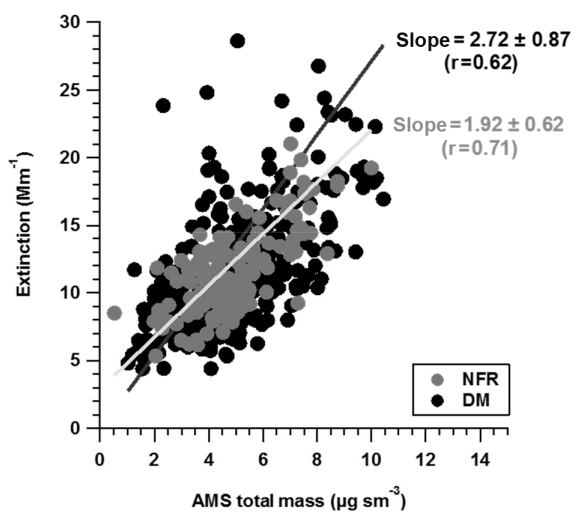

(b)

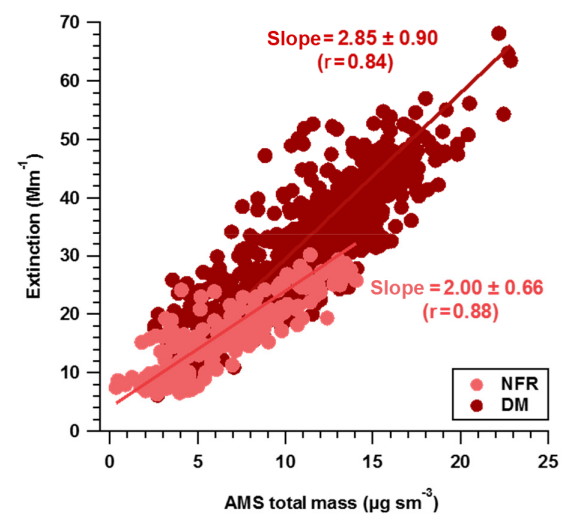

Figure 14. Mass extinction efficiency plots of $\beta_{\text {ext }}$ against total NR-PM 1 mass for NFR and DM during (a) non-cyclone and (b) cyclone episodes. Inferred slopes are derived from ODR error-weighted (10\% $\beta_{\mathrm{ext}}, 30 \%$ mAMS total mass) fits.

by a factor of 3.6. Taken together, these case scenarios suggest that meteorological transport patterns, background sulfate concentrations, and RH all have significant influences on the phase equilibrium of nitric acid and aerosol nitrate formation. Although the Denver metropolitan are is not typically in violation of the $\mathrm{PM}_{2.5}$ standard during summer months, higher aerosol nitrate concentrations may be observed in the presence of a cyclone and with $\mathrm{RH}$ values higher than what was observed during this study.

\subsection{Impacts on optical extinction}

Several studies have discussed the importance of nitratecontaining aerosols for optical extinction $\left(\beta_{\text {ext }}\right)$ coefficients, i.e., scattering and absorption of light, that impede visibility in affected regions (Tang, 1996; Watson, 2002; Li et al., 2009; Langridge et al., 2012; Zhang et al., 2012; Lei and Wuebbles, 2013). As seen in Fig. 13b, average $\beta_{\text {ext }}$ values measured during FRAPPÉ $(\lambda=632 \mathrm{~nm})$ were similar in the In-Flow, NFR, and DM region during non-cyclone days with an average of $10.6 \pm 3.5 \mathrm{M} \mathrm{m}^{-1}$, whereas factors of 1.5-3 increase in the average $\beta_{\text {ext }}$ were observed during the cyclone periods, with the most significant impact observed over DM.

Mass extinction efficiency (MEE) values, defined as the slopes of the error-weighted ( $10 \%$ for $\beta_{\text {ext }}, 30 \%$ for NR$\mathrm{PM}_{1}$ mass) linear ODR fits of $\beta_{\text {ext }}$ against total NR-PM mass, were compared in Fig. 14. MEE values under the noncyclone events in NFR and DM were $1.92 \pm 0.62 \mathrm{~m}^{2} \mathrm{~g}^{-1}$ $(r=0.71)$ and $2.72 \pm 0.87 \mathrm{~m}^{2} \mathrm{~g}^{-1}(r=0.62)$, respectively, higher by $42 \%$ in the urban center. During the cyclone events, MEE values were $43 \%$ higher over DM compared to NFR $\left(2.85 \pm 0.90 \mathrm{~m}^{2} \mathrm{~g}^{-1}(r=0.84)\right.$ and $2.00 \pm 0.66 \mathrm{~m}^{2} \mathrm{~g}^{-1}$ $(r=0.88)$, respectively) but similar to the percentage increase observed during the non-cyclone days. On cyclone days a significant increase in the average mass concentrations of the aerosol species was noted (Fig. 8). However, the similarity of the MEE percentage increase in DM during the cyclone and non-cyclone days suggests that the increase in NR-PM ${ }_{1}$ mass during the cyclone accompanied a similar increase in $\beta_{\text {ext }}$ and that MEE alone cannot provide detailed insights on the impact of the cyclone on $\beta_{\text {ext }}$ in DM.

As mentioned previously, the State of Colorado visibility standard has set a threshold of $76 \mathrm{M} \mathrm{m}^{-1}$ averaged over a $4 \mathrm{~h}$ period when $\mathrm{RH}<70 \%$. To more directly investigate how the Denver Cyclone impacted visibility in DM, we refer to the CDPHE LPV-2 long-path transmissometer measurements of ambient $\beta_{\text {ext }}$ at $550 \mathrm{~nm}$ in downtown Denver during 11:00-15:00 MST (Table 2). During the non-cyclone days (26 July, 2-3 August), the $4 \mathrm{~h}$ average values $\beta_{\text {ext }}(550 \mathrm{~nm})$ were $33-62 \mathrm{M} \mathrm{m}^{-1}$, well below the visibility standard. However, during the cyclone days (27-28 July), $4 \mathrm{~h}$ average $\beta_{\mathrm{ext}}$ $(550 \mathrm{~nm})$ values were $90-139 \mathrm{M} \mathrm{m}^{-1}$, up to a factor of $\sim 2$ higher than the standard, resulting in poor ratings with respect to the visibility standard index (VSI).

To further understand the role of different aerosol components in driving the observed increase in airborne measurements of $\beta_{\text {ext }}(632 \mathrm{~nm})$, correlations between $\beta_{\text {ext }}(632 \mathrm{~nm})$ and $\mathrm{NO}_{3}^{-}, \mathrm{OA}$, and $\mathrm{SO}_{4}^{2-}$ mass under the influence of noncyclone and cyclone air masses were examined (Fig. 15). During the non-cyclone events, $\beta_{\text {ext }}$ displayed strong correlations $(r=0.71)$ with $\mathrm{OA}$ and $\mathrm{NO}_{3}^{-}$in NFR and only with $\mathrm{OA}(r=0.70)$ in DM. $\beta_{\text {ext }}$ was poorly correlated with sulfate aerosols in the region during the non-cyclone events $(r=-0.18,0.11$, for NFR and DM, respectively). During the cyclone events, all aerosol components equally influenced $\beta_{\text {ext }}$ in NFR $(r=0.88,0.84,0.87)$, while only strong correlations with $\mathrm{NO}_{3}^{-}(r=0.86)$ were observed in DM. These results indicate that the Denver cyclone directly influenced visibility in DM by facilitating transport of an additional aerosol precursor (i.e., $\mathrm{NH}_{3}$ ) to the region compared to the non-cyclone events (detailed analysis in Sect. 3.5). 
Table 2. Summary table of $\beta_{\text {ext }}$ measurements from the Colorado Department of Public Health and Environment (CDPHE) long-path transmissometer in downtown Denver for each of the 5 days of interest. On the Visibility Standard Index Scale, a value of 101 equates to $76 \mathrm{M} \mathrm{m}^{-1}$ standard. Values between 0 and 50 are described as good, those between 51 and 100 as moderate, those between 101 and 200 as poor, and those above 201 as extremely poor visibility. NA = not available.

\begin{tabular}{|c|c|c|c|c|c|c|}
\hline Date & $\begin{array}{c}\text { Hour } \\
(\mathrm{MST})\end{array}$ & $\begin{array}{r}\beta_{\text {ext }} \\
\left(\mathrm{M} \mathrm{m}^{-1}\right)\end{array}$ & $\begin{array}{l}\mathrm{RH} \\
(\%)\end{array}$ & $\begin{array}{l}4 \mathrm{~h} \text { avg. } \\
\left(\mathrm{M} \mathrm{m}^{-1}\right)\end{array}$ & VSI & Descripto \\
\hline \multirow{5}{*}{26 July 2014} & 11:00 & 70 & 33 & 59 & 66 & Moderate \\
\hline & $12: 00$ & 50 & 29 & 59 & 66 & Moderate \\
\hline & $13: 00$ & 50 & 30 & 57 & 64 & Moderate \\
\hline & $14: 00$ & 51 & 32 & 55 & 60 & Moderate \\
\hline & $15: 00$ & 45 & 33 & 49 & 49 & Good \\
\hline \multirow{5}{*}{27 July 2014} & $11: 00$ & 124 & 66 & 139 & NA & NA \\
\hline & $12: 00$ & 108 & 61 & 125 & NA & NA \\
\hline & $13: 00$ & 95 & 53 & 113 & NA & NA \\
\hline & $14: 00$ & 110 & 49 & 109 & 145 & Poor \\
\hline & $15: 00$ & 112 & 47 & 106 & 141 & Poor \\
\hline \multirow{5}{*}{28 July 2014} & 11:00 & 118 & 56 & 118 & NA & NA \\
\hline & $12: 00$ & 108 & 51 & 112 & 149 & Poor \\
\hline & $13: 00$ & 84 & 46 & 104 & 138 & Poor \\
\hline & $14: 00$ & 78 & 43 & 97 & 129 & Poor \\
\hline & $15: 00$ & 88 & 43 & 90 & 119 & Poor \\
\hline \multirow{5}{*}{2 August 2014} & 11:00 & 38 & 33 & 44 & 43 & Good \\
\hline & $12: 00$ & 37 & 31 & 42 & 40 & Good \\
\hline & $13: 00$ & 33 & 23 & 38 & 35 & Good \\
\hline & $14: 00$ & 29 & 21 & 34 & 30 & Good \\
\hline & $15: 00$ & 32 & 21 & 33 & 28 & Good \\
\hline \multirow{5}{*}{3 August 2014} & 11:00 & 53 & 40 & 62 & 72 & Moderate \\
\hline & $12: 00$ & 44 & 34 & 57 & 63 & Moderate \\
\hline & 13:00 & 41 & 29 & 50 & 50 & Good \\
\hline & $14: 00$ & 37 & 25 & 44 & 42 & Good \\
\hline & $15: 00$ & 37 & 24 & 40 & 37 & Good \\
\hline
\end{tabular}
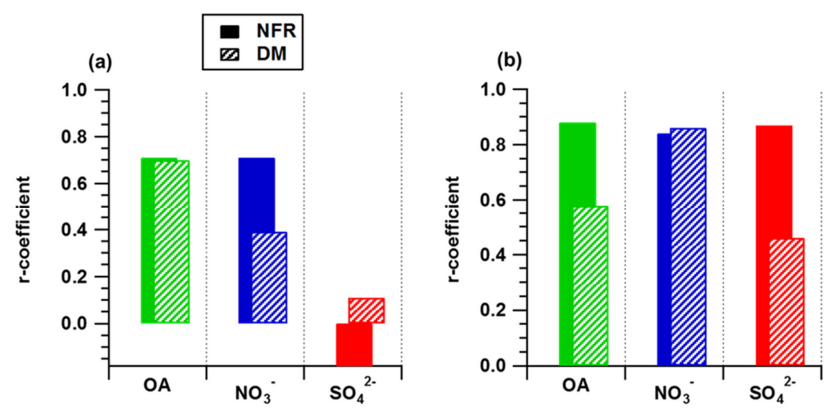

Figure 15. Correlation coefficients of scatterplots of $\beta_{\text {ext }}$ against individual aerosol species for NFR and DM during (a) non-cyclone and (b) cyclone episodes.

\section{Conclusions}

Data from the FRAPPÉ 2014 project in the Colorado Front Range were presented to understand the influence of the Denver Cyclone on source distribution and processes that impact regional air quality and visibility in the summer. The analysis demonstrated that mesoscale recirculation patterns changed the spatial distribution of pollutants emitted in the northern latitudes of the study area, transporting pollutants over DM, leading to enhanced concentration of secondary aerosol species. Overall, particle formation and growth during the non-cyclonic episodes occurred predominantly downwind of the major point/area sources. Cyclonic transport from the InFlow to NFR forced air masses with a higher concentration of trace gases towards Denver, explaining the increased mixing ratios observed in DM. Average DM concentrations of $\mathrm{OA}$ and nitrate increased by $\sim 79 \%$ and a factor of 10 , respectively, during the cyclone episodes.

The cyclonic flow facilitated transport of additional OA relative to $\mathrm{CO}$ from the northern latitudes towards DM, as seen by the increase in OA background compared to the noncyclone days. Observations showed that the MEE values in DM were similar under cyclone and non-cyclone days despite having different species (OA during non-cyclone and $\mathrm{NO}_{3}^{-}$during cyclone periods) driving $\beta_{\mathrm{ext}}(632 \mathrm{~nm})$. During 
the cyclone events, as confirmed by ISORROPIA II modeling and ground-based measurements of optical extinction, summertime visibility in the Front Range was significantly impacted by the increase in aerosol nitrate formation due to abundance of $\mathrm{NH}_{3}$ transported from the NFR region.

Overall, results from this study improve our understanding of sources and atmospheric processes responsible for summertime formation of aerosols in the greater Front Range, and the burden on air quality and regional haze. The meteorological conditions during a Denver Cyclone promote transport of aerosol constituents and their precursors from the northern Front Range into the Denver metropolitan area, increasing aerosol mass loadings and reducing visibility. Based on these results, reduction in source strengths of aerosol precursors in NFR leading to OA and ammonium nitrate formation, including mitigation of $\mathrm{NH}_{3}$ emissions from dairy and livestock farming, could effectively reduce the impact of cyclone events on Denver's air quality by reducing the aerosol mass loadings by a factor of 2 (i.e., $\sim 11$ to $5 \mu \mathrm{g} \mathrm{s} \mathrm{m}^{-3}$ ) and improving visibility by approximately 3 -fold (i.e., $\sim 32$ to $11 \mathrm{M} \mathrm{m}^{-1}$ ).

\section{Data availability}

FRAPPÉ data used in this analysis may be obtained at http://www-air.larc.nasa.gov/cgi-bin/ArcView/discover-aq. co-2014?C130=1. DISCOVER-AQ data can be obtained from the NASA Langley Research Center Atmospheric Science Data Center (doi:10.5067/Aircraft/DISCOVER$\mathrm{AQ} /$ Aerosol-TraceGas).

\section{The Supplement related to this article is available online at doi:10.5194/acp-16-12039-2016-supplement.}

Acknowledgements. Kennedy T. Vu was partially supported by the NIEHS, T32 Research Training in Environmental Toxicology Grant. The authors would like to recognize Daniel Adams and Michael Fournier (University of California, Riverside CNAS machine shop) for their technical knowledge, NCAR Research Aviation Facility (RAF) technicians for their support during integration and throughout the field campaign, Joshua Schwarz (NOAA-ESRL) for providing the secondary diffuser inlet system, Charles A. Brock (NOAA-ESRL) for providing the condensation particle counter for field calibrations, Ron Cohen and Carly Ebben (University of California, Berkeley) for TD-LIF data, and A. M. Thompson and W. Brune (NASA/Goddard and Penn State) for sonde data from the Penn State NATIVE sampling trailer. Project support and funding was from the Colorado Department of Public Health and Environment (CDPHE) as well as the USDA National Institute of Food and Agriculture, Hatch project Accession No. 233133.

Edited by: S. Brown

Reviewed by: two anonymous referees

\section{References}

Aiken, A. C., Decarlo, P. F., Kroll, J. H., Worsnop, D. R., Huffman, J. A., Docherty, K. S., Ulbrich, I. M., Mohr, C., Kimmel, J. R., and Sueper, D.: O/C and OM/OC ratios of primary, secondary, and ambient organic aerosols with high-resolution timeof-flight aerosol mass spectrometry, Environ. Sci. Technol., 42, 4478-4485, 2008.

Apel, E. C., Hornbrook, R. S., Hills, A. J., Blake, N. J., Barth, M. C., Weinheimer, A., Cantrell, C., Rutledge, S. A., Basarab, B., Crawford, J., Diskin, G., Homeyer, C. R., Campos, T., Flocke, F., Fried, A., Blake, D. R., Brune, W., Pollack, I., Peischl, J., Ryerson, T., Wennberg, P. O., Crounse, J. D., Wisthaler, A., Mikoviny, T., Huey, G., Heikes, B., O’Sullivan, D., and Riemer, D. D.: Upper tropospheric ozone production from lightning $\mathrm{NO}_{x}$-impacted convection: Smoke ingestion case study from the DC3 campaign, J. Geophys. Res.-Atmos., 120, 2505-2523, doi:10.1002/2014JD022121, 2015.

Bahreini, R., Dunlea, E. J., Matthew, B. M., Simons, C., Docherty, K. S., DeCarlo, P. F., Jimenez, J. L., Brock, C. A., and Middlebrook, A. M.: Design and operation of a pressure-controlled inlet for airborne sampling with an aerodynamic aerosol lens, Aerosol Sci. Tech., 42, 465-471, 2008.

Baker, A. K., Beyersdorf, A. J., Doezema, L. A., Katzenstein, A., Meinardi, S., Simpson, I. J., Blake, D. R., and Rowland, F. S.: Measurements of nonmethane hydrocarbons in 28 United States cities, Atmos. Environ., 42, 170-182, 2008.

Baron, J. S., Rueth, H. M., Wolfe, A. M., Nydick, K. R., Allstott, E. J., Minear, J. T., and Moraska, B.: Ecosystem Responses to Nitrogen Deposition in the Colorado Front Range, Ecosystems, 3, 352-368, doi:10.1007/s100210000032, 2000.

Bascom, R., Bromberg, P. A., Costa, D. L., Devlin, R., Dockery, D. W., Frampton, M. W., Lambert, W., Samet, J. M., Speizer, F. E., and Utell, M.: Health Effects of Outdoor Air Pollution, Part I, Am. J. Respir. Crit. Care Med., 153, 3-50, 1996.

Blett, T., Morris, K., Baron, J., Campbell, D., Cordova, K., Ely, D., Latimer, D., Mitchell, B., Shaver, C., and Silverstein, M.: Nitrogen Deposition: Issues and Effects in Rocky Mountain National Park Technical Background Document, National Park Service, Air Resources Division, Lakewood, CO, 2004.

Boy, M., Karl, T., Turnipseed, A., Mauldin, R. L., Kosciuch, E., Greenberg, J., Rathbone, J., Smith, J., Held, A., Barsanti, K., Wehner, B., Bauer, S., Wiedensohler, A., Bonn, B., Kulmala, M., and Guenther, A.: New particle formation in the Front Range of the Colorado Rocky Mountains, Atmos. Chem. Phys., 8, 15771590, doi:10.5194/acp-8-1577-2008, 2008.

Broderick, B. and Marnane, I.: A comparison of the $\mathrm{C}_{2}-\mathrm{C}_{9}$ hydrocarbon compositions of vehicle fuels and urban air in Dublin, Ireland, Atmos. Environ., 36, 975-986, 2002.

Burns, D. A.: The effects of atmospheric nitrogen deposition in the Rocky Mountains of Colorado and southern Wyoming, USA - a critical review, Environ. Pollut., 127, 257-269, 2004.

Canagaratna, M., Jayne, J., Jimenez, J., Allan, J., Alfarra, M., Zhang, Q., Onasch, T., Drewnick, F., Coe, H., and Middlebrook, A.: Chemical and microphysical characterization of ambient aerosols with the aerodyne aerosol mass spectrometer, Mass Spectrom. Rev., 26, 185-222, 2007.

Choi, Y., Vay, S. A., Vadrevu, K. P., Soja, A. J., Woo, J. H., Nolf, S. R., Sachse, G. W., Diskin, G. S., Blake, D. R., and Blake, N. J.: Characteristics of the atmospheric $\mathrm{CO}_{2}$ signal as observed over 
the conterminous United States during INTEX-NA, J. Geophys. Res.-Atmos., 113, D07301, doi:10.1029/2007jd008899, 2008.

Claeys, M., Graham, B., Vas, G., Wang, W., Vermeylen, R., Pashynska, V., Cafmeyer, J., Guyon, P., Andreae, M. O., Artaxo, P., and Maenhaut, W.: Formation of secondary organic aerosols through photooxidation of isoprene, Science, 303, 1173-1176, doi:10.1126/science.1092805, 2004.

COGCC - Colorado Oil and Gas Conservation Commission: Oil and natural gas wells data available in the "Downloads" section: http://cogcc.state.co.us/data2.html-/downloads, last access: 19 August 2016.

Countess, R. J., Wolff, G. T., and Cadle, S. H.: The Denver winter aerosol: a comprehensive chemical characterization, J. Air Pollut. Contr. Assoc., 30, 1194-1200, 1980.

Day, D., Wooldridge, P., Dillon, M., Thornton, J., and Cohen, R.: A thermal dissociation laser-induced fluorescence instrument for in situ detection of $\mathrm{NO}_{2}$, peroxy nitrates, alkyl nitrates, and $\mathrm{HNO}_{3}$, J. Geophys. Res.-Atmos., 107, ACH 4-1-ACH 4-14, 2002.

DeCarlo, P. F., Dunlea, E. J., Kimmel, J. R., Aiken, A. C., Sueper, D., Crounse, J., Wennberg, P. O., Emmons, L., Shinozuka, Y., Clarke, A., Zhou, J., Tomlinson, J., Collins, D. R., Knapp, D., Weinheimer, A. J., Montzka, D. D., Campos, T., and Jimenez, J. L.: Fast airborne aerosol size and chemistry measurements above Mexico City and Central Mexico during the MILAGRO campaign, Atmos. Chem. Phys., 8, 4027-4048, doi:10.5194/acp-84027-2008, 2008.

de Gouw, J. and Warneke, C.: Measurements of volatile organic compounds in the earth's atmosphere using proton-transferreaction mass spectrometry, Mass Spectrom. Rev., 26, 223-257, 2007.

Dockery, D. W. and Schwartz, J.: Particulate Air Pollution and Mortality: More than the Philadelphia Story, Epidemiology, 6, 629632, 1995.

Dockery, D. W., Pope, C. A., Xu, X., Spengler, J. D., Ware, J. H., Fay, M. E., Ferris, B. G., and Speizer, F. E.: An Association between Air Pollution and Mortality in Six U.S. Cities, New Engl. J. Med., 329, 1753-1759, doi:10.1056/NEJM199312093292401, 1993.

Drewnick, F., Hings, S. S., DeCarlo, P., Jayne, J. T., Gonin, M., Fuhrer, K., Weimer, S., Jimenez, J. L., Demerjian, K. L., and Borrmann, S.: A new time-of-flight aerosol mass spectrometer (TOF-AMS) - Instrument description and first field deployment, Aerosol Sci. Tech., 39, 637-658, 2005.

Edwards, P. M., Young, C. J., Aikin, K., deGouw, J., Dubé, W. P., Geiger, F., Gilman, J., Helmig, D., Holloway, J. S., Kercher, J., Lerner, B., Martin, R., McLaren, R., Parrish, D. D., Peischl, J., Roberts, J. M., Ryerson, T. B., Thornton, J., Warneke, C., Williams, E. J., and Brown, S. S.: Ozone photochemistry in an oil and natural gas extraction region during winter: simulations of a snow-free season in the Uintah Basin, Utah, Atmos. Chem. Phys., 13, 8955-8971, doi:10.5194/acp-13-8955-2013, 2013.

Ellis, R. A., Murphy, J. G., Pattey, E., van Haarlem, R., O'Brien, J. M., and Herndon, S. C.: Characterizing a Quantum Cascade Tunable Infrared Laser Differential Absorption Spectrometer (QCTILDAS) for measurements of atmospheric ammonia, Atmos. Meas. Tech., 3, 397-406, doi:10.5194/amt-3-397-2010, 2010.

Ely, D. W., Leary, J. T., Stewart, T. R., and Ross, D. M.: The establishment of the Denver visibility standard, 84th Annual Meet- ing \& Exhibition of the Air and Wasate Management Association, 16-21 June 1993, Vancouver, BC, 1993.

EPA: Federal Register Volume 73, Issue 60 (27 March 2008), edited by: EPA, Office of the Federal Register, National Archives and Records Administration, Government Publishing Office, 1643616514, 2008

EPA: Federal Register, Determinations of Attainment by the Attainment Date, Extensions of the Attainment Date, and Reclassification of Several Areas for the 2008 Ozone National Ambient Air Quality Standards (Final Rule), https://www.federalregister.gov/articles/2016/05/04/, last access: 4 May 2016.

Flocke, F.: The Front Range Air Pollution and Photochemistry Experiment (FRAPPE) - an overview, 2015 AGU Fall Meeting, 1418 December 2015, San Francisco, CA, 2015.

Fountoukis, C. and Nenes, A.: ISORROPIA II: a computationally efficient thermodynamic equilibrium model for $\mathrm{K}^{+}-\mathrm{Ca}_{2}^{+}-\mathrm{Mg}_{2}^{+}-$ $\mathrm{NH}_{4}^{+}-\mathrm{Na}^{+}-\mathrm{SO}_{4}^{2}-\mathrm{NO}_{3}-\mathrm{Cl}-\mathrm{H}_{2} \mathrm{O}$ aerosols, Atmos. Chem. Phys., 7, 4639-4659, doi:10.5194/acp-7-4639-2007, 2007.

Gentner, D. R., Isaacman, G., Worton, D. R., Chan, A. W., Dallmann, T. R., Davis, L., Liu, S., Day, D. A., Russell, L. M., and Wilson, K. R.: Elucidating secondary organic aerosol from diesel and gasoline vehicles through detailed characterization of organic carbon emissions, P. Natl. Acad. Sci. USA, 109, 18318 18323, 2012.

Gerbig, C., Schmitgen, S., Kley, D., Volz-Thomas, A., Dewey, K., and Haaks, D.: An improved fast-response vacuum-UV resonance fluorescence CO instrument, J. Geophys. Res.-Atmos., 104, 1699-1704, 1999.

Gilman, J. B., Lerner, B., Kuster, W., and De Gouw, J.: Source signature of volatile organic compounds from oil and natural gas operations in northeastern Colorado, Environ. Sci. Technol., 47, 1297-1305, 2013.

Groblicki, P. J., Wolff, G. T., and Countess, R. J.: Visibility-reducing species in the Denver "brown cloud" - I. Relationships between extinction and chemical composition, Atmos. Environ., 15, 2473-2484, 1981.

Halliday, H. S., Thompson, A. M., Wisthaler, A., Blake, D., Hornbrook, R. S., Mikoviny, T., Müller, M., Eichler, P., Apel, E. C., and Hills, A. J.: Atmospheric benzene observations from oil and gas production in the Denver Julesburg basin in July and August 2014, J. Geophys. Res.-Atmos., doi:10.1002/2016JD025327, in press, 2016.

Hallquist, M., Wenger, J. C., Baltensperger, U., Rudich, Y., Simpson, D., Claeys, M., Dommen, J., Donahue, N. M., George, C., Goldstein, A. H., Hamilton, J. F., Herrmann, H., Hoffmann, T., Iinuma, Y., Jang, M., Jenkin, M. E., Jimenez, J. L., Kiendler-Scharr, A., Maenhaut, W., McFiggans, G., Mentel, Th. F., Monod, A., Prévôt, A. S. H., Seinfeld, J. H., Surratt, J. D., Szmigielski, R., and Wildt, J.: The formation, properties and impact of secondary organic aerosol: current and emerging issues, Atmos. Chem. Phys., 9, 5155-5236, doi:10.5194/acp-9-51552009, 2009.

Holloway, J. S., Jakoubek, R. O., Parrish, D. D., Gerbig, C., VolzThomas, A., Schmitgen, S., Fried, A., Wert, B., Henry, B., and Drummond, J. R.: Airborne intercomparison of vacuum ultraviolet fluorescence and tunable diode laser absorption measurements of tropospheric carbon monoxide, J. Geophys. Res.Atmos., 105, 24251-24261, 2000. 
Huey, L. G.: Measurement of trace atmospheric species by chemical ionization mass spectrometry: Speciation of reactive nitrogen and future directions, Mass Spectrom. Rev., 26, 166-184, 2007.

Huey, L. G., Dunlea, E. J., Lovejoy, E. R., Hanson, D. R., Norton, R. B., Fehsenfeld, F. C., and Howard, C. J.: Fast time response measurements of $\mathrm{HNO}_{3}$ in air with a chemical ionization mass spectrometer, J. Geophys. Res.-Atmos., 103, 3355-3360, 1998.

Jayne, J. T., Leard, D. C., Zhang, X., Davidovits, P., Smith, K. A., Kolb, C. E., and Worsnop, D. R.: Development of an aerosol mass spectrometer for size and composition analysis of submicron particles, Aerosol Sci. Tech., 33, 49-70, 2000.

Jimenez, J. L., Jayne, J. T., Shi, Q., Kolb, C. E., Worsnop, D. R., Yourshaw, I., Seinfeld, J. H., Flagan, R. C., Zhang, X., and Smith, K. A.: Ambient aerosol sampling using the aerodyne aerosol mass spectrometer, J. Geophys. Res.-Atmos., 108, 256-2202, doi:10.1029/2001JD001213, 2003.

Jimenez, J. L., Canagaratna, M., Donahue, N., Prevot, A., Zhang, Q., Kroll, J., DeCarlo, P., Allan, J., Coe, H., and Ng, N.: Evolution of organic aerosols in the atmosphere, Science, 326, 15251529, 2009.

Karion, A., Sweeney, C., Pétron, G., Frost, G., Michael Hardesty, R., Kofler, J., Miller, B. R., Newberger, T., Wolter, S., and Banta, R.: Methane emissions estimate from airborne measurements over a western United States natural gas field, Geophys. Res. Lett., 40, 4393-4397, 2013.

Kleinman, L. I., Daum, P. H., Lee, Y. N., Senum, G. I., Springston, S. R., Wang, J., Berkowitz, C., Hubbe, J., Zaveri, R. A., and Brechtel, F. J.: Aircraft observations of aerosol composition and ageing in New England and Mid-Atlantic States during the summer 2002 New England Air Quality Study field campaign, J. Geophys. Res.-Atmos., 112, D09310, doi:10.1029/2006jd007786, 2007.

Kroll, J. H. and Seinfeld, J. H.: Chemistry of secondary organic aerosol: Formation and evolution of low-volatility organics in the atmosphere, Atmos. Environ., 42, 3593-3624, doi:10.1016/j.atmosenv.2008.01.003, 2008.

Kroll, J. H., Ng, N. L., Murphy, S. M., Flagan, R. C., and Seinfeld, J. H.: Secondary organic aerosol formation from isoprene photooxidation, Environ. Sci. Technol., 40, 1869-1877, doi:10.1021/es0524301, 2006.

Langridge, J. M., Lack, D., Brock, C. A., Bahreini, R., Middlebrook, A. M., Neuman, J. A., Nowak, J. B., Perring, A. E., Schwarz, J. P., and Spackman, J. R.: Evolution of aerosol properties impacting visibility and direct climate forcing in an ammonia-rich urban environment, J. Geophys. Res.-Atmos., 117, D00V11, doi:10.1029/2011JD017116, 2012.

Lei, H. and Wuebbles, D. J.: Chemical competition in nitrate and sulfate formations and its effect on air quality, Atmos. Environ., 80, 472-477, 2013.

Li, S., Wang, T., Zhuang, B., and Han, Y.: Indirect radiative forcing and climatic effect of the anthropogenic nitrate aerosol on regional climate of China, Adv. Atmos. Sci., 26, 543-552, 2009.

Lindinger, W., Hansel, A., and Jordan, A.: On-line monitoring of volatile organic compounds at pptv levels by means of proton-transfer-reaction mass spectrometry (PTR-MS) medical applications, food control and environmental research, Int. J. Mass Spectrom. Ion Process., 173, 191-241, doi:10.1016/S01681176(97)00281-4, 1998.
Liu, P., Ziemann, P. J., Kittelson, D. B., and McMurry, P. H.: Generating particle beams of controlled dimensions and divergence: II. Experimental evaluation of particle motion in aerodynamic lenses and nozzle expansions, Aerosol Sci. Tech., 22, 314-324, 1995a.

Liu, P., Ziemann, P. J., Kittelson, D. B., and McMurry, P. H.: Generating particle beams of controlled dimensions and divergence: I. Theory of particle motion in aerodynamic lenses and nozzle expansions, Aerosol Sci. Tech., 22, 293-313, 1995 b.

Malm, W. C., Schichtel, B. A., Barna, M. G., Gebhart, K. A., Rodriguez, M. A., Collett Jr., J. L., Carrico, C. M., Benedict, K. B., Prenni, A. J., and Kreidenweis, S. M.: Aerosol species concentrations and source apportionment of ammonia at Rocky Mountain National Park, J. Air Waste Manage. Assoc., 63, 1245-1263, 2013.

Mast, M. A. and Ely, D.: Effect of power plant emission reductions on a nearby wilderness area: a case study in northwestern Colorado, Environ. Monit. Assess., 185, 7081-7095, 2013.

Middlebrook, A. M., Bahreini, R., Jimenez, J. L., and Canagaratna, M. R.: Evaluation of composition-dependent collection efficiencies for the aerodyne aerosol mass spectrometer using field data, Aerosol Sci. Tech., 46, 258-271, 2012.

Monks, P., Granier, C., Fuzzi, S., Stohl, A., Williams, M., Akimoto, H., Amann, M., Baklanov, A., Baltensperger, U., and Bey, I.: Atmospheric composition change - global and regional air quality, Atmos. Environ., 43, 5268-5350, 2009.

Na, K., Song, C., Switzer, C., and Cocker, D. R.: Effect of ammonia on secondary organic aerosol formation from $\alpha$-pinene ozonolysis in dry and humid conditions, Environ. Sci. Technol., 41, 6096-6102, 2007.

Nanus, L., Campbell, D. H., Ingersoll, G. P., Clow, D. W., and Mast, M. A.: Atmospheric deposition maps for the Rocky Mountains, Atmos. Environ., 37, 4881-4892, 2003.

Neff, W. D.: Meteorological classifications used in the 19871988 Denver Brown Cloud Study, 6th Joint Conference on Applications of Air Pollution Meteorology, 30 January-3 February 1989, Anaheim, CA, 1989.

Neff, W. D.: The Denver Brown Cloud studies from the perspective of model assessment needs and the role of meteorology, J. Air Waste Manage. Assoc., 47, 269-285, 1997.

Nenes, A., ISORROPIA: Aerosol Thermodynamic Model \& Adjoint: http://isorropia.eas.gatech.edu/ (last access: 3 March 2016), 2013.

Ng, N. L., Kroll, J. H., Chan, A. W. H., Chhabra, P. S., Flagan, R. C., and Seinfeld, J. H.: Secondary organic aerosol formation from $m$-xylene, toluene, and benzene, Atmos. Chem. Phys., 7, 3909-3922, doi:10.5194/acp-7-3909-2007, 2007.

Odum, J. R., Hoffmann, T., Bowman, F., Collins, D., Flagan, R. C., and Seinfeld, J. H.: Gas/particle partitioning and secondary organic aerosol yields, Environ. Sci. Technol., 30, 2580-2585, doi:10.1021/es950943+, 1996.

Pandis, S. N., Harley, R. A., Cass, G. R., and Seinfeld, J. H.: Secondary Organic Aerosol Formation and Transport, Atmos. Environ. A, 26, 2269-2282, doi:10.1016/0960-1686(92)90358-r, 1992.

Pétron, G., Frost, G., Miller, B. R., Hirsch, A. I., Montzka, S. A., Karion, A., Trainer, M., Sweeney, C., Andrews, A. E., and Miller, L.: Hydrocarbon emissions characterization in the Col- 
orado Front Range: A pilot study, J. Geophys. Res.-Atmos., 117, D04304, doi:10.1029/2011JD016360, 2012.

Pétron, G., Karion, A., Sweeney, C., Miller, B. R., Montzka, S. A., Frost, G. J., Trainer, M., Tans, P., Andrews, A., and Kofler, J.: A new look at methane and nonmethane hydrocarbon emissions from oil and natural gas operations in the Colorado DenverJulesburg Basin, J. Geophys. Res.-Atmos., 119, 6836-6852, 2014.

Pollack, I., Ryerson, T., Trainer, M., Parrish, D., Andrews, A., Atlas, E., Blake, D., Brown, S., Commane, R., and Daube, B.: Airborne and ground-based observations of a weekend effect in ozone, precursors, and oxidation products in the California South Coast Air Basin, J. Geophys. Res.-Atmos., 117, D00V05, doi:10.1029/2011jd016772, 2012.

Pope, C. A., Bates, D. V., and Raizenne, M. E.: Health effects of particulate air pollution: time for reassessment?, Environ. Health Perspect., 103, 472-480, 1995.

Pope, C. A., Burnett, R. T., Thun, M. J., Calle, E. E., Krewski, D., Ito, K., and Thurston, G. D.: Lung Cancer, Cardiopulmonary Mortality, and Long-term Exposure to Fine Particulate Air Pollution, J. Am. Med. Assoc., 287, 1132-1141, doi:10.1001/jama.287.9.1132, 2002.

Pope, C. A., Ezzati, M., and Dockery, D. W.: Fine-Particulate Air Pollution and Life Expectancy in the United States, New Engl. J. Med., 360, 376-386, doi:10.1056/NEJMsa0805646, 2009.

Pope III, C. A., Thun, M. J., Namboodiri, M. M., Dockery, D. W., Evans, J. S., Speizer, F. E., and Heath Jr., C. W.: Particulate air pollution as a predictor of mortality in a prospective study of US adults, Am. J. Respir. Crit. Care Med., 151, 669-674, 1995.

Pöschl, U.: Atmospheric aerosols: Composition, transformation, climate and health effects, Angew. Chem. Int. Edn., 44, 75207540, doi:10.1002/anie.200501122, 2005.

Reddy, P. J. and Pfister, G. G.: Meteorological factors contributing to the interannual variability of mid-summer surface ozone in Colorado, Utah, and other western US states, J. Geophys. Res.Atmos., 121, 2434-2456, doi:10.1002/2015jd023840, 2016.

Reddy, P. J., Barbarick, D., and Osterburg, R.: Development of a statistical model for forecasting episodes of visibility degradation in the Denver metropolitan area, J. Appl. Meteorol., 34, 616-625, 1995.

Richter, D., Weibring, P., Walega, J. G., Fried, A., Spuler, S. M., and Taubman, M. S.: Compact highly sensitive multi-species airborne mid-IR spectrometer, Appl. Phys. B, 119, 119-131, 2015.

Ridley, B., Ott, L., Pickering, K., Emmons, L., Montzka, D., Weinheimer, A., Knapp, D., Grahek, F., Li, L., and Heymsfield, G.: Florida thunderstorms: A faucet of reactive nitrogen to the upper troposphere, J. Geophys. Res.-Atmos., 109, D17305, doi:10.1029/2004jd004769, 2004.

Riva, M., Robinson, E. S., Perraudin, E., Donahue, N. M., and Villenave, E.: Photochemical Aging of Secondary Organic Aerosols Generated from the Photooxidation of Polycyclic Aromatic Hydrocarbons in the Gas-Phase, Environ. Sci. Technol., 49, 54075416, 2015.

Rogers, D.: Air Sample Inlets for RAF Aircraft, http:// www.eol.ucar.edu/homes/dcrogers/Instruments/Inlets/ (last access: 21 April 2015), 2011.

Russell, P. A.: Denver Air Pollution Study - 1973, Proceedings of a Symposium Vol. I, EPA Report No. EPA-600/9-76-007a, Denver
Research Institute, University of Denver Colorado, Winter Denver Urban Plume Study Symposium, Denver, CO, 1976.

Schell, B., Ackermann, I. J., Hass, H., Binkowski, F. S., and Ebel, A.: Modeling the formation of secondary organic aerosol within a comprehensive air quality model system, J. Geophys. Res.Atmos., 106, 28275-28293, doi:10.1029/2001jd000384, 2001.

Seinfeld, J. H. and Pandis, S. N.: Atmospheric chemistry and physics: from air pollution to climate change, John Wiley \& Sons, Hoboken, NJ, 2012.

Slusher, D. L., Huey, L. G., Tanner, D. J., Flocke, F. M., and Roberts, J. M.: A thermal dissociation-chemical ionization mass spectrometry (TD-CIMS) technique for the simultaneous measurement of peroxyacyl nitrates and dinitrogen pentoxide, J. Geophys. Res.-Atmos., 109, D15S10, doi:10.1029/2004jd004670, 2004.

Song, C., Na, K., and Cocker, D. R.: Impact of the hydrocarbon to $\mathrm{NO}_{x}$ ratio on secondary organic aerosol formation, Environ. Sci. Technol., 39, 3143-3149, 2005.

Stelson, A. and Seinfeld, J. H.: Relative humidity and temperature dependence of the ammonium nitrate dissociation constant, Atmos. Environ., 16, 983-992, 1982.

Stelson, A., Friedlander, S., and Seinfeld, J.: A note on the equilibrium relationship between ammonia and nitric acid and particulate ammonium nitrate, Atmos. Environ., 13, 369-371, 1979.

Stocker, T., Qin, D., Plattner, G., Tignor, M., Allen, S., Boschung, J., Nauels, A., Xia, Y., Bex, B., and Midgley, B.: IPCC, 2013: climate change 2013: the physical science basis, in: Contribution of working group I to the fifth assessment report of the intergovernmental panel on climate change, Cambridge University Press, Cambridge, UK and New York, NY, USA, , 2013.

Swarthout, R. F., Russo, R. S., Zhou, Y., Hart, A. H., and Sive, B. C.: Volatile organic compound distributions during the NACHTT campaign at the Boulder Atmospheric Observatory: Influence of urban and natural gas sources, J. Geophys. Res.-Atmos., 118, 10614-10637, 2013.

Sueper, D.: ToF-AMS Analysis Toolkit, available at: http://cires1. colorado.edu/jimenez-group/ToFAMSResources/ToFSoftware/, last access: 17 December 2014.

Szoke, E. J.: Eye of the Denver cyclone, Mon. Weather Rev., 119, 1283-1292, 1991.

Szoke, E. J. and Augustine, J.: A decade of tornado occurrence associated with a surface mesoscale flow feature - The Denver cyclone, Preprints, 16th Conf. Severe Local Storms, Kananaskis Park, Alberta, Canada, 554-559, 1990.

Szoke, E. J., Barjenbruch, D., Glancy, R., and Kleyla, R.: The Denver Cyclone and Tornadoes 25 Years Later: The Continued Challenge of Predicting Non-Supercell Tornadoes, 23rd Conference on Severe Local Storms, American Meteorological Society, St. Louis, MO, 2006.

Takegawa, N., Kita, K., Kondo, Y., Matsumi, Y., Parrish, D., Holloway, J., Koike, M., Miyazaki, Y., Toriyama, N., and Kawakami, S.: Airborne vacuum ultraviolet resonance fluorescence instrument for in situ measurement of CO, J. Geophys. Res.-Atmos., 106, 24237-24244, 2001.

Tang, I. N.: Chemical and size effects of hygroscopic aerosols on light scattering coefficients, J. Geophys. Res., 101, 1924519250, 1996.

Thompson, A. M., Stauffer, R. M., Miller, S. K., Martins, D. K., Joseph, E., Weinheimer, A. J., and Diskin, G. S.: Ozone profiles 
in the Baltimore-Washington region (2006-2011): satellite comparisons and DISCOVER-AQ observations, J. Atmos. Chem., 72, 393-422, 2015.

Thompson, C. R., Hueber, J., and Helmig, D.: Influence of oil and gas emissions on ambient atmospheric non-methane hydrocarbons in residential areas of Northeastern Colorado, Elementa, 2, 000035, doi:10.12952/journal.elementa.000035, 2014.

Thompson, T. M., Rodriguez, M. A., Barna, M. G., Gebhart, K. A., Hand, J. L., Day, D. E., Malm, W. C., Benedict, K. B., Collett, J. L., and Schichtel, B. A.: Rocky Mountain National Park reduced nitrogen source apportionment, J. Geophys. Res.-Atmos., 120, 4370-4384, doi:10.1002/2014JD022675, 2015.

Thornton, J. A., Wooldridge, P. J., and Cohen, R. C.: Atmospheric $\mathrm{NO}_{2}$ : In situ laser-induced fluorescence detection at parts per trillion mixing ratios, Anal. Chem., 72, 528-539, 2000.

Toth, J. J. and Johnson, R. H.: Summer Surface Flow Characteristics over Northeast Colorado, Mon. Weather Rev., 113, 1458-1469, doi:10.1175/1520-0493(1985)113<1458:SSFCON>2.0.CO;2, 1985.

Turpin, B. J. and Huntzicker, J. J.: Identification of Secondary Organic Aerosol Episodes and Quantitation of Primary and Secondary Organic Aerosol Concentrations During SCAQS, Atmos. Environ., 29, 3527-3544, doi:10.1016/1352-2310(94)00276-q, 1995.

Turpin, B. J. and Lim, H.-J.: Species contributions to PM $_{2.5}$ mass concentrations: Revisiting common assumptions for estimating organic mass, Aerosol Sci. Tech., 35, 602-610, 2001.

Valavanidis, A., Fiotakis, K., and Vlachogianni, T.: Airborne Particulate Matter and Human Health: Toxicological Assessment and Importance of Size and Composition of Particles for Oxidative Damage and Carcinogenic Mechanisms, J. Environ. Sci. Health C, 26, 339-362, doi:10.1080/10590500802494538, 2008.

Volkamer, R., Jimenez, J. L., San Martini, F., Dzepina, K., Zhang, Q., Salcedo, D., Molina, L. T., Worsnop, D. R., and Molina, M. J.: Secondary organic aerosol formation from anthropogenic air pollution: Rapid and higher than expected, Geophys. Res. Lett., 33, L17811, doi:10.1029/2006g1026899, 2006.

von Hessberg, C., von Hessberg, P., Pöschl, U., Bilde, M., Nielsen, O. J., and Moortgat, G. K.: Temperature and humidity dependence of secondary organic aerosol yield from the ozonolysis of $\beta$-pinene, Atmos. Chem. Phys., 9, 3583-3599, doi:10.5194/acp9-3583-2009, 2009.

von Stackelberg, K., Buonocore, J., Bhave, P. V., and Schwartz, J. A.: Public health impacts of secondary particulate formation from aromatic hydrocarbons in gasoline, Environ. Health, 12, doi:10.1186/1476-069x-12-19, 2013.

Warneke, C., Gouw, J. A., Edwards, P. M., Holloway, J. S., Gilman, J. B., Kuster, W. C., Graus, M., Atlas, E., Blake, D., and Gentner, D. R.: Photochemical aging of volatile organic compounds in the Los Angeles basin: Weekday-weekend effect, J. Geophys. Res.Atmos., 118, 5018-5028, 2013.

Warner, J. X., Wei, Z., Strow, L. L., Barnet, C. D., Sparling, L. C., Diskin, G., and Sachse, G.: Improved agreement of AIRS tropospheric carbon monoxide products with other EOS sensors using optimal estimation retrievals, Atmos. Chem. Phys., 10, 95219533, doi:10.5194/acp-10-9521-2010, 2010.
Watson, J. G.: Visibility: Science and regulation, J. Air Waste Manage. Assoc., 52, 628-713, 2002.

Watson, J. G., Chow, J., Richards, L., Andersen, S., Houck, J., and Dietrich, D.: The 1987-88 Metro Denver Brown Cloud Air Pollution Study, in: Vol. II: Measurements, DRI document, F2, prepared for 1987-1988 Metro Denver Brown Cloud Study, Inc., Greater Denver Chamber of Commerce, Denver, CO, by Desert Research Institute, Reno, NV, 1988.

Watson, J. G., Fujita, E. M., Chow, J. C., Zielinska, B., Richards, L. W., Neff, W., and Dietrich, D.: Northern front range air quality study final report, Colorado State University, Office of the Vice President for Research and Information Technology, Desert Research Institute, Reno, NV, 1998.

Weibring, P., Richter, D., Fried, A., Walega, J., and Dyroff, C.: Ultra-high-precision mid-IR spectrometer II: system description and spectroscopic performance, Appl. Phys. B, 85, 207-218, 2006.

Weibring, P., Richter, D., Walega, J. G., and Fried, A.: First demonstration of a high performance difference frequency spectrometer on airborne platforms, Opt. Express, 15, 13476-13495, 2007.

Wilczak, J. M. and Christian, T. W.: Case Study of an Orographically Induced Mesoscale Vortex (Denver Cyclone), Mon. Weather Rev., 118, 1082-1102, doi:10.1175/15200493(1990)118<1082:CSOAOI>2.0.CO;2, 1990.

Wilczak, J. M. and Glendening, J. W.: Observations and MixedLayer Modeling of a Terrain-Induced Mesoscale Gyre: The Denver Cyclone, Mon. Weather Rev., 116, 2688-2711, doi:10.1175/1520-0493(1988)116<2688:OAMLMO>2.0.CO;2, 1988.

Williams, M. W. and Tonnessen, K. A.: Critical loads for inorganic nitrogen deposition in the Colorado Front Range, USA, Ecol. Appl., 10, 1648-1665, 2000.

Wilson, R. and Spengler, J. D.: Particles in our air: concentrations and health effects, Harvard School of Public Health Cambridge, MA, 1996.

Wolff, G., Countess, R., Groblicki, P., Ferman, M., Cadle, S., and Muhlbaier, J.: Visibility-reducing species in the Denver "brown cloud" - II. Sources and temporal patterns, Atmos. Environ., 15, 2485-2502, 1981.

Zhang, H., Shen, Z., Wei, X., Zhang, M., and Li, Z.: Comparison of optical properties of nitrate and sulfate aerosol and the direct radiative forcing due to nitrate in China, Atmos. Res., 113, 113125, 2012.

Zhang, Q., Canagaratna, M. R., Jayne, J. T., Worsnop, D. R., and Jimenez, J. L.: Time-and size-resolved chemical composition of submicron particles in Pittsburgh: Implications for aerosol sources and processes, J. Geophys. Res.-Atmos., 110, D07S09, doi:10.1029/2004jd004649, 2005.

Zhang, Q., Jimenez, J. L., Canagaratna, M. R., Ulbrich, I. M., Ng, N. L., Worsnop, D. R., and Sun, Y.: Understanding atmospheric organic aerosols via factor analysis of aerosol mass spectrometry: a review, Anal. Bioanal. Chem., 401, 3045-3067, 2011. 